\title{
AZ ÉSZAKNYUGAT-DUNÁNTÚL TÉRSÉGÉNEK GAZDASÁGI ADOTTSÁGAI ÉS VERSENYELŐNYEI
}

\author{
(Economic Endowments and Competitive Advantages of the \\ Northwest Transdanubian Region)
}

\section{RECHNITZER JÁNOS}

A négy megyét (Győr-Moson-Sopron, Vas, Veszprém, Zala) magában foglaló Északnyugat-Dunántúl térsége ${ }^{1}$ sem mentes a magyarországi modernizáció területi ellentmondásaitól.

A térség gazdasági szerkezetében meghatározó szerepet jảtszó ipari bázisban a nehézipart (bányászat, vegyipar, hadiipar) tömörítỏ centrumok és vonzáskörzeteik tartós válsággal küszködtek, míg a könnyüipari (textil, textilruházati, cipóipar, fa- és fafeldolgozóipar) és építőipari ágazatokat fogadó városok is hirtelen veszitették el piacaikat, így a többségében monolitikus gazdasági szerkezetek összeroppantak. Mindez jelentơs foglalkoztatási feszültséggel és tartós megélhetési gondokkal járt együtt. A piacképes termékeket elöállító, a tartósan nyugati exportkapcsolatokkal rendelkezó ágazatok viszont képesek voliak a termék- és piacszerkezet gyors váltására. Ennek megfelelően ezen centrumokban a gazdasági szervezetek átalakulása már a kilencvenes évek elején lezajlott, amit számottevő külföldi érdeklốdés is kísért ${ }^{2}$. Ugyanakkor a térségben, s kiemelten annak nagycentrumaiban a vállalkozás aktivitás élénkebb volt, mivel a külföldi befektetések szélesebb ágazati kört fogtak át, a lokális és regionális fogyasztási piac növekedésében nem voltak érzékelhető megtorpanások, s mindez együttjárt a szolgáltatások egyre szélesebb skálájának megtelepedésével. A térségben a települések infrastrukturális ellátottsága valamivel kedvezőbb mint az országos átlag, a népesség képzettsége, termelési tapasztalatai sokoldalúbbak, éppen a jelentös ipari tradíciók miatt, továbbá a szolgáltatások egyre szélesebb körének megjelenését tapasztaljuk, ami nemcsak a gazdasági szerkezet átalakulását jelzi, hanem a helyi és térségi piacok megélénkülését is. Végezetül a települések környezeti megújítása is megkezdödött, ami érzékelteti a háztartások és önkormányzatok gazdasági stabilizálódását, illetve az egyre igényesebb életkörülmények iránti igények és feltételek megjelenését.

Az Északnyugat-Dunántúl térsége sem mentes a problémáktól. A fejlödést hordozó nagycentrumok, illetve az azokat összekötó közlekedési hálózat mentén szerveződő aktívabb települési zónákon kívül eső mikrorégiókban figyelhetỏk meg a területi válság különféle formái. A belső perifériák a megyehatárok mentén ${ }^{3}$ húzódnak, ahol részben a kistérségi szervezö centrumok hiánya miatt ${ }^{4}$, részben a kedvezötlen infrastrukturális ellátottság következtében ${ }^{5}$, részben pedig a mezőgazdasági foglalkoztatási lehetőségek radikális csökkenése okán, tartós leszakadással kell számolni. 
A térség egészének észak-déli közlekedési kapcsolatai gyengék, így a belső együttmúködések még esetlegesek, de a nyugat-keleti kapcsolatok is túlterheltek ${ }^{6}$, már nem képesek követni és fogadni a gyorsan fejlődő nagycentrumok és térségeik egymás közötti növekvő forgalmát. A koncentrált környezeti problémákkal sújtott térségek; a Duna eltereléséből fakadó vízpótlás ökológiai gondja a Szigetközben jelentkezik, a bányavidéken a karsztvizek elvesztéséböl fakadó tartós szint- és hömérsékletcsökkenéssel kell számolni (Tapolcai-medence, Dunántúliközéphegység), míg Ajkán, Várpalotán a lég- és porszennyezés okoz problémát, illetve akadályozza a gazdasági szerkezet átalakítását.

A tanulmány célja, hogy alapos áttekintést adjon az Északnyugat-Dunántúl térsége gazdasági szerkezetét alakító különféle faktorokról (vállalkozások, külföldi tőke, privatizáció, foglalkoztatás), értékelje a telephelyi és telepítési tényezőket mind térségi, mind országos összevetésben, s végül a gazdasági bázis fejlesztésének föbb irányait foglalja össze.

\section{A gazdaság szervezeti átalakulása; a vállalkozások}

A gazdasági rendszerváltozás felszabadította a vállalkozások alapitása és müködése elé állított akadályokat, így azok száma évről-évre ugrásszerüen növekedett. A térségben a gazdasági szervezetek száma szintén dinamikusan nőtt (1. táblázat). A térség éppen a jogi személyiséggel rendelkezö társaságok esetében tudta egyenletesen megtartani arányát ( $10 \%$ körül) az országban, miközben a két idöpont között a szervezetek alakulásának növekedési üteme közel megegyezett az országos tendenciákkal. A nem jogi személyiséggel rendelkező, tehát kevésbé tökeigényes társasági formában viszont a térség részesedése az országból 176,4\%kal növekedett a vizsgált idöszakban, miközben 2,5-szer több szervezet alakult. Hasonlóan dinamikus arányokat tapasztalhatunk az egyéni vállalkozások esetében is, hiszen a térségben megháromszorozódott ezen vállalkozások száma, mialatt annak részesedése közel egyharmaddal nỏtt az országon belül, s minden hetedik egyéni vállalkozás a térségben alakult meg.

\section{TÁBLÁZAT}

A gazdasági szervezetek számának változása országosan és a térségben

Transition of the number of economic companies in Hungary and the region

\begin{tabular}{|l|c|c|c|c|c|c|c|c|c|}
\hline \multicolumn{1}{|c|}{ Évek } & \multicolumn{3}{|c|}{$\begin{array}{c}\text { Jogi személyiségü } \\
\text { gazdasági szervezetek }\end{array}$} & \multicolumn{2}{c|}{$\begin{array}{c}\text { Nem jogi személyiségú } \\
\text { gazdasági szervezetek }\end{array}$} & \multicolumn{3}{c|}{ Egyéni vallalkozások } \\
\hline & Ország & Térség & $\begin{array}{c}\text { Térség } \\
\text { rész. (\%) }\end{array}$ & Ország & Térség & $\begin{array}{c}\text { Térség } \\
\text { rész. (\%) }\end{array}$ & Ország & Térség & $\begin{array}{c}\text { Térség } \\
\text { rész. (\%) }\end{array}$ \\
\hline 1990 & 29470 & 2971 & 10,1 & 66817 & 3737 & 5,5 & - & 34441 & - \\
\hline 1991 & 52576 & 5144 & 9,8 & 83784 & 5464 & 6,5 & 511786 & 55901 & 10,9 \\
\hline 1992 & 69386 & 6868 & 9,9 & 70597 & 6791 & 9,6 & 606201 & 84258 & 13,9 \\
\hline 1993 & 84959 & 8493 & 10,0 & 98036 & 9513 & 9,7 & 688843 & 96544 & 14,0 \\
\hline $\begin{array}{l}\text { Változás } \\
1993 / 1990(\%)\end{array}$ & 288,3 & 285,9 & 99,0 & 146,7 & 254,6 & 176,4 & 134,6 & 280,3 & 128,3 \\
\hline
\end{tabular}

Forrás: Területi statisztikai évkönyvek 
A gazdasági szervezeteken belül mélyreható átstrukturálódást figyelhetünk meg. Tekintsük át a következökben a vállalatok és néhány kedvelt társasági formában tevékenykedö szervezetek időbeli változását a térségben (2. táblázat)

\section{TÁBLÁZAT \\ A gazdasági szervezetek száma az Északnyugat-Dunántúlon \\ Number of economic organisation in Northwest Transdanubia}

\begin{tabular}{|l|c|c|c|c|}
\hline \multicolumn{1}{|c|}{ Évek } & Vállalat & $\begin{array}{c}\text { Korlátolt } \\
\text { felelösségú } \\
\text { társaság }\end{array}$ & Részvénytársaság & Betéti társaság \\
\hline 1990 & 312 & 1524 & 47 & 515 \\
\hline 1991 & 301 & 3585 & 91 & 2325 \\
\hline 1992 & 226 & 5264 & 156 & 3756 \\
\hline 1993 & 137 & 6840 & 237 & 6232 \\
\hline Változás 1993/1990 (\%) & 43.9 & 448.8 & 504.2 & 1210.0 \\
\hline $\begin{array}{l}\text { Térség részesedése } \\
\text { a vidékból 1993-ban (\%) }\end{array}$ & 20.2 & 17.3 & 19.2 & 14.6 \\
\hline
\end{tabular}

Forrás: Területi statisztikai évkönyvek.

Az állami vállalatok aránya látványosan visszaesett a térségben, azok száma részben az átalakulás, részben pedig a privatizáció miatt több, mint a felére csökkent. A korlátolt felelösségü társaságok száma 4,5-szeresére emelkedett, hasonlóan a nagyobb tőkeigényt megkövetelö részvénytársuságokhoz, ahol viszont a szervezetek növekedési dinamikája már ötszörös.

A részvénytársaságoknál egy kicsit el kell időznünk. Hiszen ezen gazdálkodási forma nemcsak a nagyobb tőkeigényt képviseli, hanem gazdasági potenciált is megtestesít, mivel a nagyobb tőkebevonás - részvények tőzsdei bevezetése lehetősségeit kínálhatja. Nos, a részvénytársaságok számának növekedési üteme a térségben meghaladja a vidéki átlagot (értéke 141,8\%, míg a térség változása $151,2 \%$ volt 1992 és 1993 között), $s$ ennek köszönhetö, hogy a térségben található a vidék minden ötödik részvénytársasága. A megyék közül a vizsgált szervezetekből a legtöbb, 82 egység Győr-Moson-Sopron megyében van (34,5\%), miközben Vas $(191,7 \%)$ és Zala megyében $(162,5 \%)$ a részvénytársaságok számának változása jóval a vidéki átlagos növekedési ủtem felett volt 1992 és 1993 kőzött.

A betéti társaságok száma 12-szeresére emelkedett a térségben a vizsgált időszakban. Ennek a legegyszerübb társasági formának a népszerủsége 1991-töl ugrik meg, hiszen ekkor még magas adókedvezményt kaptak az új vállalkozások, illetve szinte alaptöke nélkül lehet a betéti társaságokat létrehozni, így terjedésük látványos.

Országos kitekintésben a vállalkozási formák föbb csoportjai már kủlönböző területi ősszefüggések alapján terjednek (1.ábra). Egyértelmüen kitünik az ábrából, hogy az ország nyugati és keleti térségei között - éppen a vidéki átlagok alapján kimutatható kulönbségek vannak. A gazdasági társaságok az országot északnyugat, a nem jogi személyiségü társaságok közép és két déli sziget, az egyéni vállalkozások pedig délnyugat ", súlyossá" teszik. S éppen ezen utóbbi vállalkozási formának a 

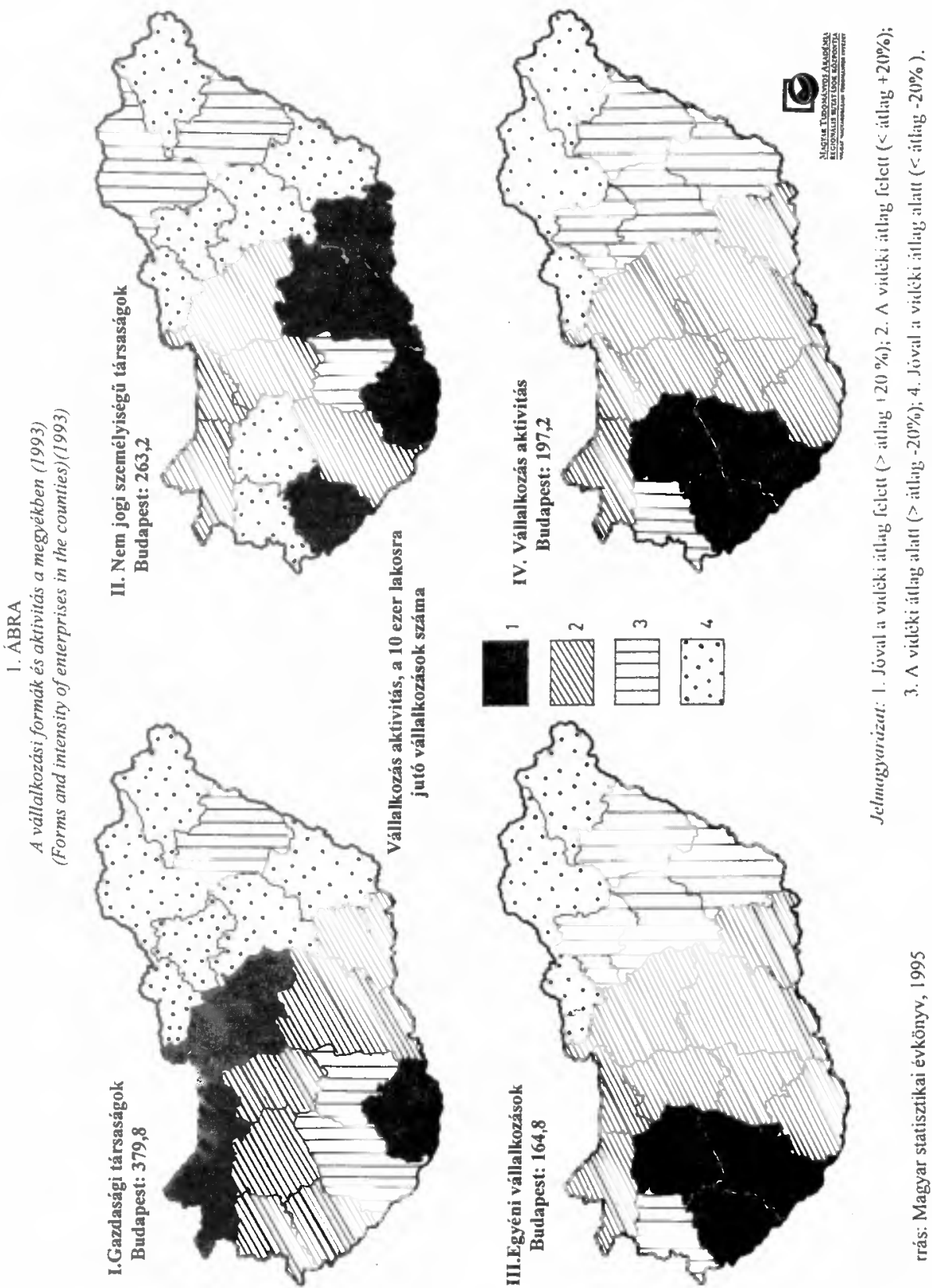

 
meghatározó többsége miatt a vállalkozás aktivitás, azaz a 10 ezer lakosra jutó vállalkozások számát tekintve a délnyugati térségek súlypontja válik meghatározóvá. Ugyanakkor nagyon élesen kimutatható a vállalkozások terjedésében a határozott törésvonal, pontosabban szakadék, ami a SzegedSalgótarján vonal mentén húzódik. A Tiszántúl, valamint az északkeleti térségek a vállalkozások által kevésbé preferáltak.

Ebben az országos összevetésben térségünk és annak megyéi különféleképpen viselkednek. A gazdasági társaságok vonatkozásában Györ-Moson-Sopron megye kimagasló dinamikát képvisel, míg a többi megye a vidéki átlag körüli értéket nyújtja. A nem jogi személyiségủ gazdasági társaságok terjedése Zalában a legkedvezőbb, Győr-Moson-Sopron megyében a vidéki átlagot éri el, a másik két megyében ezen érték alatt van, sôt Vasban az országos áttekintést véve, a legalacsonyabb a kisebb tőke igényủ szervezeti formák megjelenése. Az egyéni vállalkozások képe is vegyes a térség megyéiben, többségben vannak az átlag feletti aktivitást mutatók, a legnépszerübb vállalkozási formában tevékenykedők sủrüsége egyedül Vas megyében - kisebb mértékben - kerül a vidéki átlag alá.

A térségben tehát két végletet tapasztalhatunk, egyik irányra kimondottan a tỏkebefektetést igénylő gazdasági társaságok terjedése a jellemző, másik irányra pedig az egyéni vállalkozások megtelepedése, ezen utóbbiak többsége a déli és a keleti megyéket, azoknak jobbára az idegenforgalom által preferált területeiben koncentrálódnak.

A három fö vállalkozási forma alapján számított vállalkozás sürüség időbeli trendjei alapján a térség megyéiben a növekedés ugyan egyenletes volt 1990 és 1993 között, azonban annak dinamikája már a megyékben eltérő, változó mértékü. Érdekes, hogy az induló évben még nem volt jelentős szórás a térség megyéi között. 1990-től aztán egyes megyék meglódultak, majd telítődés jegyeit mutatják (GyőrMoson-Sopron), míg más megyénél az egyes szervezeti formákban a vállalkozás aktivitás már kimerülőben van, vagy jelentősebben mérséklődött, míg a többi területi egységben még tartósan emelkedő, sőt növekvő a "vállalkozás alapítási kedv" (Zala megye). Végül egyenletesen, de visszafogottan növekszik a különféle vállalkozási formák száma Vas, illetve Veszprém megyében, ahol az ütem országos viszonylatban inkább közepesnek, mint kiemelkedőnek tekinthető.

A vállalkozások terjedésének árnyalatnyi eltérései még nem tükrözik a térség és a megyék gazdasága strukturális átrendeződésének befejeződését. Viszont már egyértelmüsítik, hogy a jelenlegi szerkezetek radikális megváltozása csak valamilyen, az egész nemzetgazdaságot érintő gazdasági átrendezés esetében lehetséges. Ennek megfelelóen a térség és a megyék gazdasága szervezeti rendszerének jelenlegi szerkezetével hosszú távon kell számolnunk.

A vállalkozások terjedését tehát azok jellege egyértelmüen behatárolja. Ugyanakkor a kủlönféle típusú szervezetek más és más szükségletek alapján jönnek létre, amelyek viszont már eröteljesen kötődnek a településekhez, azoknak a településhálózatban elfoglalt helyzetéhez. A vállalkozás aktivitás - koncentrálva a gazdasági szervezetekre - a térség településeinek szintjén 1990-ben és 1994-ben lényeges változásokat tükröz. Az első megállapítás, hogy a diffúzió üteme növekedett, azaz egyre több telepůlésben jelentek meg vállalkozások, hiszen 625-röl 467-re csökkent azon telepủlések száma, ahol nem találtunk gazdasági szervezetet. 
A terjedés együttjárt a koncentrációval is, mivel látványosan nött azon központok száma, ahol 15-nél több szervezet múködött, mig 1990-ben ez az érték a térség településeinek 15,2\%-át jellemezte, addig 1994-re már 35,1\%-át. S végül a térségben vannak egybefüggö térségek, ahol egyáltalán nem tüntek fel a vállalkozások (Dél-Rábaköz, Bakony felvidék, zalai aprófalvak), kialakulnak emellett koncentrációk (a nagyvárosok és térségük, határátkelök vidéke), valamint egybefüggö zónák, sávok (Balaton környéke, az M1-es autópálya térsége, a 8-as föútvonal egyes szakaszai), ahol viszont már egyre több vállalkozás talál magának alkalmas telephelyet, müködési lehetöséget.

\section{A gazdaság teljesitőképessége}

A térségben tehát formálódik a lokális és a regionális piac, $\mathrm{s}$ azt érdemes mélyebb bontásban, azaz a városok és azok vonzáskörzeteinek viszonylatában alaposan szemügyre venni. A térség négy megyéjének 28 városkörzete közül mindössze két Veszprém megyei (a sümegi és a zirci) és egy Zala megyei (a letenyei) bizonyult mind 1992-ben, mind pedig 1993-ban az országos vizsgálatba bevont 182 városkörzet között az átlagosnál viszonylag fejletlenebbnek.

Jellemző az, hogy mind a négy megyében a gazdaság szempontjából meghatározó centrumok körzete - a nagykanizsait kivéve - általában az elsó húsz-harminc között található, tehát viszonylagos fejlettségük illeszkedik a megyéjük pozíciójához. Mindezekböl következik, hogy az átlagos megyei gazdasági adaptációs képesség mögött nincsenek országos mércével mérve jelentös belsó városkörzeti szóródások, a gazdasági átalakulás szempontjából fontosabb folyamatok térségen belüli terjedése viszonylag egyenletesnek mondható.

Györ-Moson-Sopron megyében a „névadó" három történeti város körzete a meghatározó: mind országos, mind pedig térségi összehasonlitásban relatív fejlődőképességük, gazdaságuk pozíciója a legjobbak első harmadába-negyedébe sorolódik. Györ körzetében leginkább a népesség jövedelmi pozíciója és a vállalkozás-terjedés, Mosonmagyaróvár környékén a vegyes vállalatok aránya. Sopron térségében pedig a kedvezö foglalkoztatási helyzet és vegyes vállalati arány emelendő ki a leginkább. (Amellett, hogy föként Sopron, de a másik két város környékében sem tapasztalható az egyes tényezöket tekintve szembetűnő aránytalanság, kiegyensúlyozott az adaptációs képességük). Csorna és Kapuvár térsége országos mércével a középmezỏny felsö részébe, térségi viszonyításban pedig a gyengébb pozícióban lévök utolsó harmadába került. Hasonlóképpen a fejlettebbek csoportjához, csak ellentétes iránnyal ebben a két körzetben is viszonylag kiegyenlített az átlagos pozíció mögötti tényezők képe: a foglalkoztatási helyzet aránylag kedvezöbb volta mellett a másik három elemet nézve egyöntetú a lemaradás mind - és föleg - a megyei, mind a térségi összevetésben. Mindemellett az országos rangsor szerinti sorrendi helyzet javulása a felzárkózási folyamat elörehaladását mutatja.

Vas megyében Szombathely körzetének a pozíciója (az egyedüli) meghatározó, a megye többi zónája átlagos alkalmazkodó képességet mutat. Ez utóbbi körből Körmend és Köszeg környéke emelhető talán csak ki (elsősorban a javuló foglalkoztatási és lakossági jövedelmi lehetőséggel), amellett, hogy azért mindegyik 
városkörnyék országos összehasonlitásban az átlagosnál jobb fejlödőképességet és gyorsabb alkalmazkodást mutat, a sorrendi pozíciójuk általában javul. Celldömölk és különösen Vasvár körzete esetében lassú a vállalkozásterjedés, kevés a lakossági jövedelem és a foglalkoztatási helyzet is problematikus. Szentgotthárd környéke - az egyik legkisebb térségbeli mikrokörzet - az adatok tanúsága szerint egyelöre kialakulatlan, hektikusan változó gazdasági pozíciót mutat, elöbb-utóbb azonban a helyzete minden bizonnyal - egy jó közepes szinten - stabilizálódik, még akkor is, ha az autógyártó üzem közvetlen térségi szervezö-fejlesztő hatást a környezetére csak fokozatosan gyakorolja.

Veszprém megye - miként arra már a megyei helyzet értékelésénél utaltunk - a városkörzetek pozícióját, a fejlődöképesség alakulását tekintve, két részre szakad. A dinamikusabb térségi mozgás a Balaton-partra és Veszprém környékére koncentrálódik, a többi viszont erösen közepes vagy még annál is gyengébb zóna, ráadásul 1993-ra - itt-ott igen erős - relatív pozícióvesztést is mutatva. Sümeg körzete a térség legfejletlenebb (elmaradott, rurális jellegü) vidéke szinte mindegyik alapmutató szerint, változás egyelöre nem tapasztalható. Pápa és Zirc körzetében az alaptényezök mutatóinak nagysága, alakulása alapján fennáll a veszélye annak, hogy a sümegi terïlet sorsára juthatnak, gazdasági-körzeti karakterük amúgy hasonló. Várpalota és Ajka térsége jellegzetesen depressziós övezet (magas munkanélküliség, alacsony és stagnáló vagy csökkenő lakossági jövedelem, gyenge vállalkozási aktivitás, a külföldi töke érdektelensége), az ajkai esetében még inkább a romló, a várpalotait tekintve azonban már jellemzöbben a kilábaló szakaszban.

Zala megye korábban jeizett felzárkózását ismételten a Balaton-part, valamint Zalaegerszeg környéke produkálja. A többi városkörzet - amelyek történetileg elmaradott vagy rurális térségek, hiszen a korábbi országos elhatárolások is ebbe a kategóriába sorolták e településeket, 1986-tól szinte folyamatosan - potenciálja egyelöre gyenge, tényezőnként néhány helyen a helyzet javulására utaló jegyekkel találkozunk (például a zalaszentgróti és a letenyei körzetnél a vállalkozási készség javult, előbbinél beleértve a vegyes vállalati kategóriát is), de nagytérségi viszonyitásban még gyorsan romló foglalkoztatási helyzettel. A legmeglepóbb a nagykanizsai térség fejlődési ütemvesztése - remélhetőleg átmeneti -, lecsúszása. A térségi léptékkel gyors munkanélküliség növekedés - egyelőre a lakossági jövedelmek relatíve erőteljesebb emelkedésével párosulva - a fejlődési elözményeket figyelembe véve, egy helyi (részben depressziós, részben rurális) válság kibontakozására utal, halaszthatatlan szerkezetváltási kényszert hozva létre.

A (magyar) gazdaság fejlődésének térszerkezeti jellegzetessége miatt a városkörzetek „természetes" jellemzöje az, hogy a centrum - már csak népességi súlya miatt is meghatározza a körzetét, koncentrálja a fejlödés lehetőségét. Ez azt jelenti, hogy a fentiekben leirt városkörzeti kép a centrumokat magukat is többé-kevésbé jellemzi, ahhoz képest azonban a központi városok általában jobb helyzetben vannak.

A városkörzetekhez hasonlóan a térségben itt összesen három egység tekinthetö országos összehasonlításban az átlagosnál gyengébb helyzetünek: Sümeg, Letenye és Várpalota (Zirc pozíciója lényegesen jobb a saját összevetésében, mint a körzetének). Vagyis összességében és általában a térség városainak fejlödöképessége, gazdasági pozíciója illeszkedik a többi vizsgált területi metszetnél is kimutatható relatív (az ország egészéhez viszonyítva mért) fejlettséghez. Az 
eltérések jellemzően strukturális problémákat jelenítenek meg, ily módon tipikusan a belső erőforrásokra és aktivitásra támaszkodó regionális fejlesztési politika címzettjei lehetnek.

A 28 értékelt térségbeli város közül tíz olyant találunk, ahol az a körzetével együtt a többi körzethez viszonyitva relative fejlódóképesebb, mint a központja a városok (Budapest nélkül vett) összességéhez képest: Györ-Moson-Sopron megyében nincs ilyen, Vas megyében Köszeg, Szentgotthárd és Szombathely, Veszprém megyében Balatonfüred, Sümeg, Tapolca, Várpalota és Veszprém, Zala megyében pedig Hévíz és Letenye (2. ábra).

Ez persze egyfelől akár pozitív is lehet, hiszen a különbségek leginkább azt mutatják, hogy az egyébként relatíve jobb pozícióban levő városkörzeteknél (mint például a korábbiak szerint a szombathelyi, veszprémi, balatonfüredi és hévízi körzetek esetében) a központot egy, az átlagosnál dinamikusabb településhalmaz veszi körbe, a fejlődés lehetősége nem csak egyetlen központon áll vagy bukik.

Problematikussá a különbség akkor válhat, ha a környezet együttesen rosszabb pozícióját még a központi város saját gyengesége is terheli. Ilyen értelemben Szentgotthárd, Sümeg, Letenye, valamint Várpalota jelenti a térségben a gyenge láncszemet. Az első három a gazdasági potenciál oldaláról egyelöre nem alkalmas a körzetközponti szerepkörre (más funkciókat tekintve talán igen), térségük külsö centrumok támogatására is rászorul. Várpalota annyiban más eset, hogy minden valószínüség szerint a szerkezetváltási kényszer miatt átmenetileg vesztette el „rögzitett" funkcióját.

A négy megyét magában foglaló nagytérség összességében - a föváros és az ahhoz közvetlenül kapcsolódó térségek mellett - minden rendelkezésre álló tényinformáció alapján az ország relative legstabilabb és legdinamikusabb térsége ma. E stabilitás és dinamika ugyan tagolt, megyei és kistérségi szinten árnyaltabb minősítést kiván, de tény, hogy az elemeiben itt is fellelhetö térségi elmaradottság (elszigetelt aprófalvak) és a válság jegyek (Veszprém megye néhảny iparvárosa) nem tủnnek olyan kiterjedtnek és végletes mélységünek, mint az ország más (elsősorban északkeleti) térségeiben.

A relatív stabilitást és dinamikát a térségben az alábbi tényezők képviselik:

- a munkanélküliség viszonylag alacsony szintje,

- a rendkívül intenzív külföldi tókevonzás,

- a térség gazdaságának erỏs exportorientáltsága.

Ezek a jellemzők azt igazolják, hogy a formálódó piacgazdaság struktúra-átalakitó folyamatai épp azokat a tényezőket, adottságokat értékelték fel, amellyel a térség egésze s különösen egyes zónái, körzetei rendelkeznek. A fejlödést hordozó tényezók közül kiemelésre érdemesek az alábbiak:

- A kedvezó földrajzi fekvés, amely az alapjaiban keleti (volt szovjet) irányú gazdasági kötődések helyébe lépö domináns nyugati (elsósorban német, osztrák, olasz) gazdasági kapcsolatrendszer eredményeként a nyugati országrészeket felértékelte. A lokalizáció differenciáló hatását a földrajzi helyzetben meglévö objektív különbségekhez képest megsokszorozza az a tény (a nyugati térségek javára), hogy az ország keleti térségi irányába kiépítetlenek a modern közlekedési-kommunikációs kapesolatok (pl. autópályák). A fekvési előnyhöz kapcsolható faktor az is, hogy lényegében az osztrák-magyar kapcsolatok 


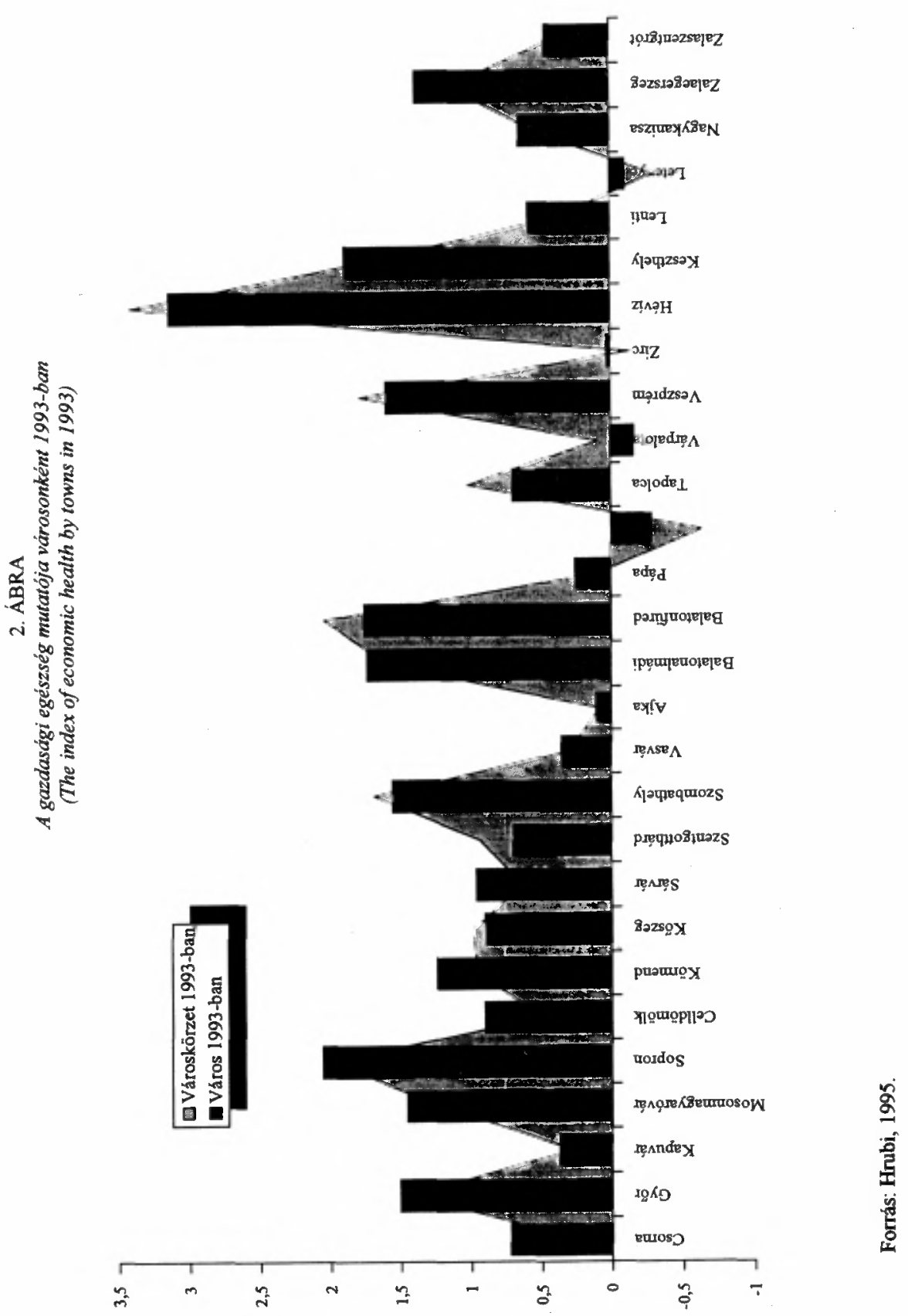


jelentik ma egyedül azt a szomszédsági-relációt, amelyet sem a történeti (nemzetiségi) bizalmatlanság, sem a közvetlen gazdasági és/vagy katonai krizishelyzet nem akadályoz érdemben. A fekvési előnyök szerepét tovább fokozza az, hogy az új gazdasági struktúrában kiemelkedő a súlya a kereskedelemi, áruforgalmi szférának, illetve az ipari-termelö tevékenységeken belül a „kapcsolat-intenziv" bedolgozói, összeszerelői profilnak. A fekvés pozitív hozadékai remélhetőleg ellensúlyozzák azt a kockázatot, amely a térségnek az ország belső területeitől való gazdasági elszakadásához, egyoldalú külsö függéséhez vezethet. (A belsỏ gazdasági kapcsolatok dezintegrálódása, illetve külső függésbe fordulása az átmenetben egyébként az egész országban jellemzö negatívum, $s$ egyik legnagyobb fékje a válságtérségek meglendülésének, hiszen azok nem kapcsolódnak a dinamikus centrumokhoz, fejlesztési impulzusokat onnan nem kapnak.)

- A térség gazdasági-ágazati szerkezetében viszonylag csekély volt a struktúraváltásnak radikálisan áldozatul eső anyagigényes nehézipar (kohászat, bányászat) aránya. E tekintetben a térség (a közép-dunántúli ipari övezeteket kivéve) ma tulajdonképp annak előnyeit is élvezi, hogy az ötvenes-hatvanas években politikai okok miatt nem részesült az extenziv iparosítás áldásaiból. Jórészt ez az ágazati meghatározottság eredményezte, hogy a térség gazdasága mély krízis nélkül - mi több, nem egy elemében már ma bővülve - halad át a tulajdoni és szervezeti átalakuláson, a privatizáció, a modernizáció fázisain.

- Bár nehezen számszerüsíthető, de feltételezhető tényezőként kell számba venni a konszolidáltnak tekinthetö társadalmi összetételt, a nagyobb termelési, vállalkozói és munkaismereteket, azaz a mobil humán kapacitásokat. Már a hetvenes években ezen térségekben megkezdódött, éppen az osztrák határ menti helyzetből, de az intenzívebb nyugati export kapcsolatok miatt is a piacgazdasági minták megismerése, azok fokozatos elsajátítása, az ehhez kötódó különféle tényezők terjedése (fogyasztás, menedzsment magatartás, életmód, vállalkozás, külföldi kapcsolatok stb.). Mindezek piacgazdaságba történő átmenetnél a térséget - különösen annak osztrák határ menti övezeteit kedvezóbb helyzetbe hozta, egy gyorsabb fordulatot eredményezve, s így a négy megye, ebból különösen Györ-Moson-Sopron és Vas szinte az egész ország számára a modernizáció vidéki (területi) zászlóshajóinak tekinthetők.

A felsorolt elöny tényezők, kedvező adottságok a térségben tagoltan mutatkoznak meg. A vizsgálatok a térség négy megyéje között dinamikai-fejlettségi és karakterbeli különbségeket egyaránt kimutatnak. Összességében a legkedvezőbb helyzetünek Györ-Moson-Sopron megye van, ezt Vas követi. A két megyében a földrajzi egymásmellettiség ugyan nagyon hasonló gazdasági karakterrel párosul, de vannak szembetủnő különbségek. Györ-Moson-Sopron megyében a gazdasági bázis sokkal karakteresebb, annak nagyobb hagyományai vannak, szélesebb gazdasági kapcsolatai, egyben képzettebb, nagyobb tapasztalatokkal rendelkező humán kapacitások is rendelkezésre állnak. Vas megyében ugyan látványos a külföldi tőke megtelepedése azonban a humántőke fokozatosan kimerül, a gazdasági bázishoz még nem tudtak felzárkózni a szolgáltatási rendszerek (üzleti és pénzügyi szolgáltatások), a megye egycentrumú, illetve a tartós megújítás bázisai $(\mathrm{K}+\mathrm{F})$ teljes mértékben hiányoznak. A másik két megye a térség valódi "magja”, Zala és 
Veszprém már sajátos, elkülönítő jegyeket mutat. Zalát a határ menti fekvés rokonitja (Szlovénia is fejlett, dinamikus szomszédnak minősíthetö, ugyanakkor a megyével közvetlenül érintkező szlovén térségek, települések döntően elmaradottak, periférikus helyzetủek) a két másik határ menti megyével, speciális, kétközpontú városhálózata és faluhálózatának egyértelmủ aprófalvas karaktere, a fỏ közlekedésikommunikációs tengelyekhez képest periférikus helyzete azonban el is választja tölưk. Megítélésünk szerint Veszprém ma még csak reménybeli „nyugati” megye, de kedvező adottságokkal, hiszen jelentősek a termelési tapasztalatok, viszonylag széles telephelyi kínálatot nyújthat és a tartós fejlödést segítő kutatás-fejlesztési feltételek is adottak.

Gazdasági súlyát tekintve a térség legnagyobb centruma Györ, az egyes megyéken belül pedig egyöntetủen a megyeszékhelyek jelentik a legfontosabb gazdasági központot. Györ súlya a térségen belül azonban távolról sem olyan domináns, mint a többi nagytérség központjánál (pl. Pécs, Szeged, Debrecen). A központi helyzetủ regionális centrum hiánya is egyik determinánsa a térség viszonylagos tagoltságának. A megyeszékhelyek relatív stabilitásának a piaci szféra mellett alaptényezöje még ma is a közszolgáltató infrastruktúra nagy súlya. A legnagyobb központokban e tényező stabilizáló hatásának tartós fennmaradása valószinüsíthető az államháztartási reform „karcsúsítô" hatásai dacára is, ami viszont egy stabil lokális piacot biztosíthat, $\mathrm{s}$ teret nyithat a szolgáltatási szféra fejlődésének.

Ha nem az abszolút gazdasági súlyt tekintjük, hanem a relatív jelzöszámokat, akkor egyértelmüen Sopron az, amely országos összevetésben a legnagyobb arányban koncentrálja a piacgazdasági átmenet dinamikahordozó jegyeit és leginkább mentes a válságjegyektől. A megyeszékhelyeken kívüli telepưléskörböl kiemelkedik Mosonmagyaróvár, illetve Nagykanizsa. Veszprém megye - a megyeszékhely kivételével - rendelkezik instabil gazdasági kơzponthálózattal: Pápa - ismert tradíciói ellenére - továbbra sem mutat érzékletes felzárkózást, s a hagyományos ipari centrumok (,szocialista városok”) depressziós jellegủek.

A térséget nem is elsődlegesen a nagy centrumok tagolják, hanem dinamikájukat és gazdasági karakterüket tekintve, jól elkülönithetô zónák, tengelyek (3. ábra). E zónákat a fekvési elönyök, speciális térségi adottságok, illetve a közlekedési tengelyek jelölik ki. Ilyen övezet:

- az osztrák-magyar határmente (Szentgotthárd, Szombathely, Köszeg, Sopron), amelynek alapkarakterét a kiugró külföldi tökevonzás adja, a zónától kelet felé távolodva lejtöszerủen csökkennek a jelzett hatások,

- hasonló karakterü a Hegyeshalom-Mosonmagyaróvár-Györ vonal, amelyben közlekedési tengelyvonalként a (kis és kőzép)vállalkozói aktivitásnak is kiemelt a szerepe, illetve ennek a zónának a fokozatos kiépülése Sopron irányába, a 85ös föközlekedési út mentén,

- harmadik dinamikus övezetként az északi Balaton-part turisztikai-idegenforgalmi vállalkozási zónája emelhető ki,

- a negyedik gazdasági tömörülés részben a - Balaton parthoz is kapcsolódik, önálló, elsősorban ipari karakterrel rendelkezik - a Veszprém-Várpalota-Ajka városegyüttes, amely egyre eröteljesebben kötődik a látványosan fejlődő székesfehérvári innovációs pólushoz. 


\section{3. ÁBRA}

Az Északnyugat-Dunántúl térségeinek és városainak gazdasági potenciálja

(Economic potential of the regions and towns in North Transdanubia)

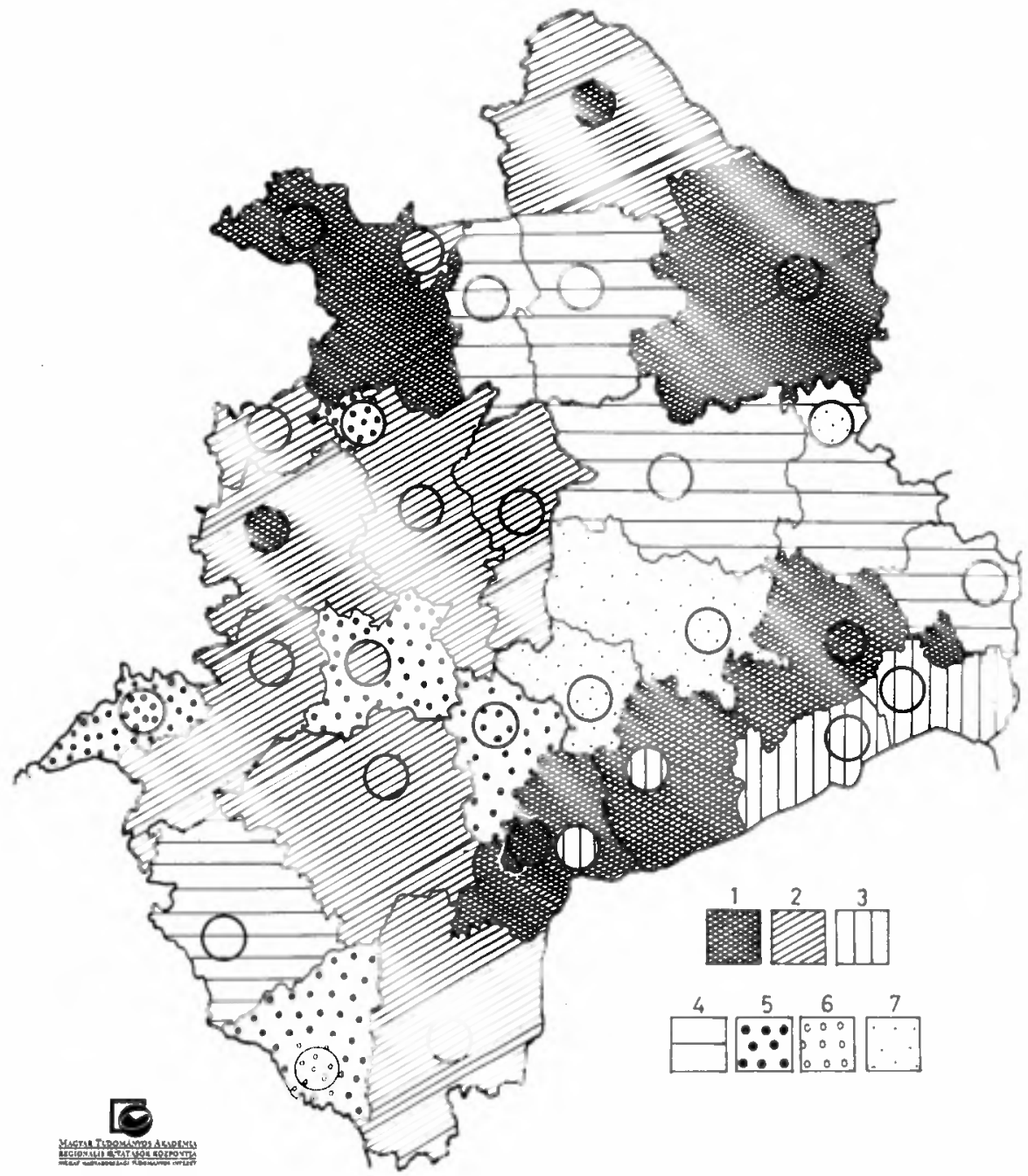

1. aktív, az országos átlagnál kedvezöbb gazdaságı környezet - 2 stabıl munkavállalói pozició. erös külfoldi tôkevonzás. gyenge vállalkozói aktivitás . 3. stabil munkavalllaloi pozició kiugró vállalkozási aktivitás gyenge külföldi tókebevonás - 4 stabil munkavällalói pozició. alacsony vállalkozás aktivitás és küiföld tö́kevonzás - 5. kedvezötlen vállalkozói pozició. jelentös válialkozás aktivitás és külföldi tökevonzás - 6 kedvezötlen munkavállalói pozició és vállalkozói aktivitás. jelentös külfoldi tökevonzás - 7 atlą alatti pozíció mindhárom tényezöben 
A négy tengely között országos összevetésben ugyan az átlagnál kedvezőbb helyzetủ térség található, de relatív értelemben a Csorna-Kapuvár-Sárvár-VasvárCelldömölk-Ajka-Pápa-Zirc vonal által közrefogott mezotérség, belsö perifériának minősíthetö. (Érzékletes hiányként mutatkozik itt egy Sárvár-Pápa-Kisbér-Komárom közlekedési tengely.) Ez a térség választja le a nyugati dinamikus zónáktól Veszprém és Zala életképes centrumait.

\section{A külföldi tỏke jelenléte}

A területi gazdasági szerkezet átalakulásának, de egyben versenyképességének fontos mutatója, hogy a külföldi tóke milyen tömegben és arányban jelent meg az adott térségben, illetve melyek azok a föbb tőkeexportör országok, melyekhez a regionális szerkezetek kötődnek.

A külföldi tỏke területi terjedését a szervezetek száma és a tökeimport mértéke alapján a 3. táblázat mutatja be 1990-töl 1994-ig, évente. Az országban az idöszak végére közel 26 ezer szervezetben volt 480 milliárd Ft értékủ külföldi érdekeltség, a vállalkozásokból 12,8\%, míg a tökeállományból viszont csak 9,7\% települt meg az Északnyugat-Dunántúlon. A tőkeimportban a tỏkenagyságot tekintve nem, míg a szervezetek számát nézve viszont 3,5\%-kal növelte a térség az arányát a vizsgált négy esztendö alatt, igy lényegében azt mondhatjuk, hogy minden tizedik forint országosan és minden negyedik forint a vidéki relációban a külföldi befektetésekból itt realizálódott.

Ha csak a vidéki viszonylatot vizsgáljuk, ahol 1994-re a szervezetek 46,9\%-a és a tökeállomány 40,9\%-a található, akkor az Északnyugat-Dunántúl négy megyéje együttesen még jobb helyzetben van, hiszen a szervezetekben $27,2 \%$-ot, mig a tökebefektetések vonatkozásában már 23,8\%-ot tudhat magának. A befektetések nagyságát az is jelzi, hogy egy külföldi érdekeltségü gazdasági szervezetre milyen nagyságú tőkeimport jut. Nos, a térségben ez az érték ugyancsak 1994-ben 14,0 millió Ft, míg a megyék átlagában már 16,1 és az országos viszonylatban 18,5 millió Ft, ami azt jelzi, hogy a térségben többségében az utóbbi időben ugyan nốtt a szervezetek száma, azonban ezekre nem a nagy, hanem inkább a kis- és közepes befektetések érvényesek. Mindezt igazolja az is, hogy a térség vonatkozásában 1992-ben az egy szervezetre jutó külföldi tỏke nagysága 18,4 millió Ft volt, ami 1994-re a fenti nagyságra esett vissza.

A térség megyéiben a külföldi tőke fỏbb jellemzöit a 4. táblázatban foglaltuk össze. Látható, hogy a megyék között jelentős különbségek vannak a külföldi töke fogadásában, a térséget nem lehet egységesen kezelni. Györ-Moson-Sopron megye kedvező adottságai miatt, így a határ menti helyzet, a megfelelö települési infrastruktúra, a képzett munkaerö, a viszonylag magas szinvonalú termelói infrastruktúra, országosan a megyék közül, de a térség vonatkozásában is a tőkeimport fö telephely fogadói között van. 1992 után már mérséklödött a külföldi érdeklödés Magyarország iránt, egyik esztendőröl a másikra a tökebeáramlás jelentösen csökkent, inkább a szervezetek száma növekedett, ami Györ-MosonSopron megyében szintén kimutatható, azaz az utóbbi esztendökben, vagyis 1993-tól inkább a kisebb tökét képviselö szervezetek nagyobb számban jelentek meg a megyében. Vas megyében jelentős külföldi befektetések történtek (GM Opel), ami 


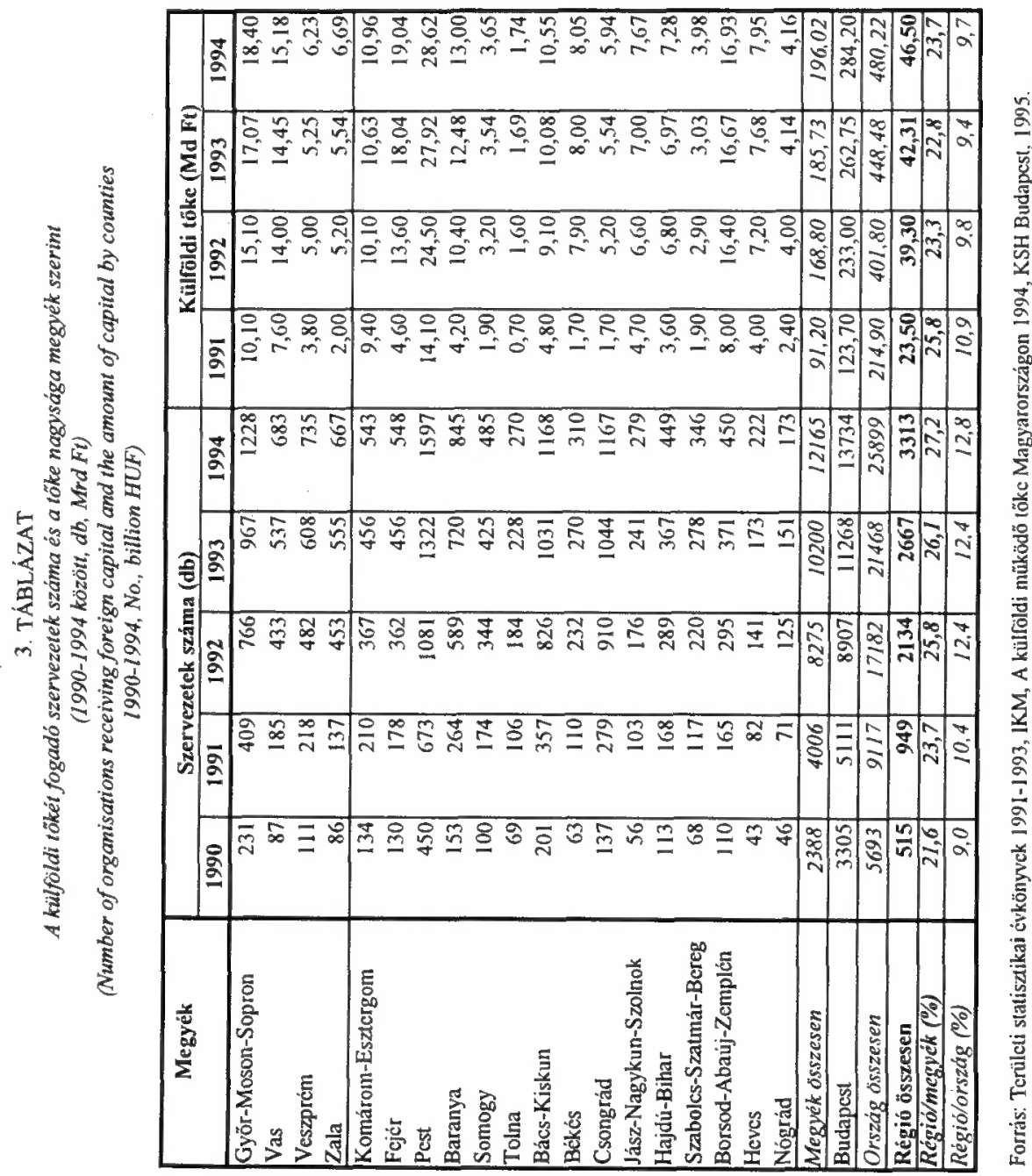


hirtelen megnövelte a megye arányát az országos befektetésekböl, így az egy szervezetre jutó tőkeállomány 1992-ben még a budapesti átlagot $(26,2$ millió $\mathrm{Ft})$ is meghaladta. A beruházások mérséklése után visszaesett Vas megyében a külföldi tőke fogadásának üteme, a megyében inkább a kisebb és kevésbé tökeerös külföldi érdekeltségú vállalkozások jelentek meg, majd napjainkra ismét megjelentek a nagybefektetők

\section{TÁBLÁZAT}

A külföldi töke néhány jellemzöje az Északnyugat-Dunántúl megyéiben, 1994 Some features of foreign capital in the Nortwest Transdanubian counties, 1994

\begin{tabular}{|c|c|c|c|c|}
\hline Megnevezés & Györ-M.S. & Vas & Veszprém & Zala \\
\hline Töke aránya az országból (\%)! & 6,4 & 3,2 & 1,3 & 1,4 \\
\hline a megyékbő́l $(\%)$ & 9,3 & 7,7 & 3,2 & 3,4 \\
\hline a térségböl $(\%)$ & 39,5 & 32,7 & 13,4 & 14,4 \\
\hline Tökenövekedés (1992-1994) (\%) & 121,8 & 108,4 & 124,6 & 128,6 \\
\hline Szervezet aránya az országból (\%) & 4,7 & 2,6 & 2,8 & 2,5 \\
\hline a megyékböl $(\%)$ & 10,1 & 5,6 & 6,0 & 5,4 \\
\hline a térségböl $(\%)$ & 37,1 & 20,6 & 22,2 & 20,1 \\
\hline Egy szervezetre jutó tôkeállomány 1994 (millió Ft) & 14,9 & 22,2 & 8,5 & 10,0 \\
\hline 1992 (millió Ft) & 19,7 & 32,3 & 10,3 & 11,5 \\
\hline
\end{tabular}

Forrás: Területi statisztikai évkönyvek

Zala és Veszprém megyében a külföldi tỏke megtelepedését vizsgálva, hasonló tendenciákat ismerhetünk fel. A nagyobb számú, kimondottan kisebb tökét megmozgató szervezetek jelentek meg a megyékben, amelyeknek a részesedése a térségben közel azonos a szervezetek számát és a tőkeállományt is figyelembe véve.

A külföldi tőke származási helyét is célszerü az elemzés során számba venni (4. ábra). A térségben, de az egyes megyékben is az osztrák érdekeltség volt a meghatározó a szervezetek és a tőkeállomány vonatkozásában is. A tőkenagyságot tekintve a vizsgált esztendöben a németországi befektetök a térségben magas arányt képviseltek, mindezt a kisebb számú, de tökeerösebb befektetésekben realizálták (például Győr-Moson-Sopron megyében), míg másutt nagyobb számú, viszont kisebb tökeállományt képviselö vállalkozásokat alapítottak (például Zala és Veszprém megye). A FÁK országoknak, igy Oroszországnak volt egy jelentős privatizációs kivásárlása 1993-ban Zala megyében, ami szinte - néhány kisebb, nem tökeerős vállalkozáson túl - egyedül képviseli az orosz érdeklődést a térségben. Nagyobb befektetỏ országnak kellene tekinteni a térségben Olaszországot, hiszen a térség - egyes feltételezések szerint - egyre határozottabban az olasz gazdasági érdekkörbe tartozik. Nos, ennek hatása egyáltalán nem érzódik, a minimális olasz befektetések kevés számú szervezetben realizálódtak, inkább azt mondhatjuk, hogy az olasz töke csupán érdeklödik a térség iránt, ugyan az összes vidéki befektetések 14\%-a a térségben realizálódott. Az Egyesült Államokból származó befektetók viszont jelen vannak a térségben, itt inkább a közepes, mint a kisbefektetések a jellemzöek, s ennek következtében a vidéki tỏkeállomány minden harmadik forintját ebből az országból a térségbe fektették be 1993-ban. 


\section{4. ÁBRA}

A vegyesvállalatok száma és a jegyzett tóke nagysága az Északnyugat-Dunántúlon származási országok szerint 1989-1994

Number of joint ventures and amount of capital assets in North Transdanubia. by countries of origin, 1989-1994)

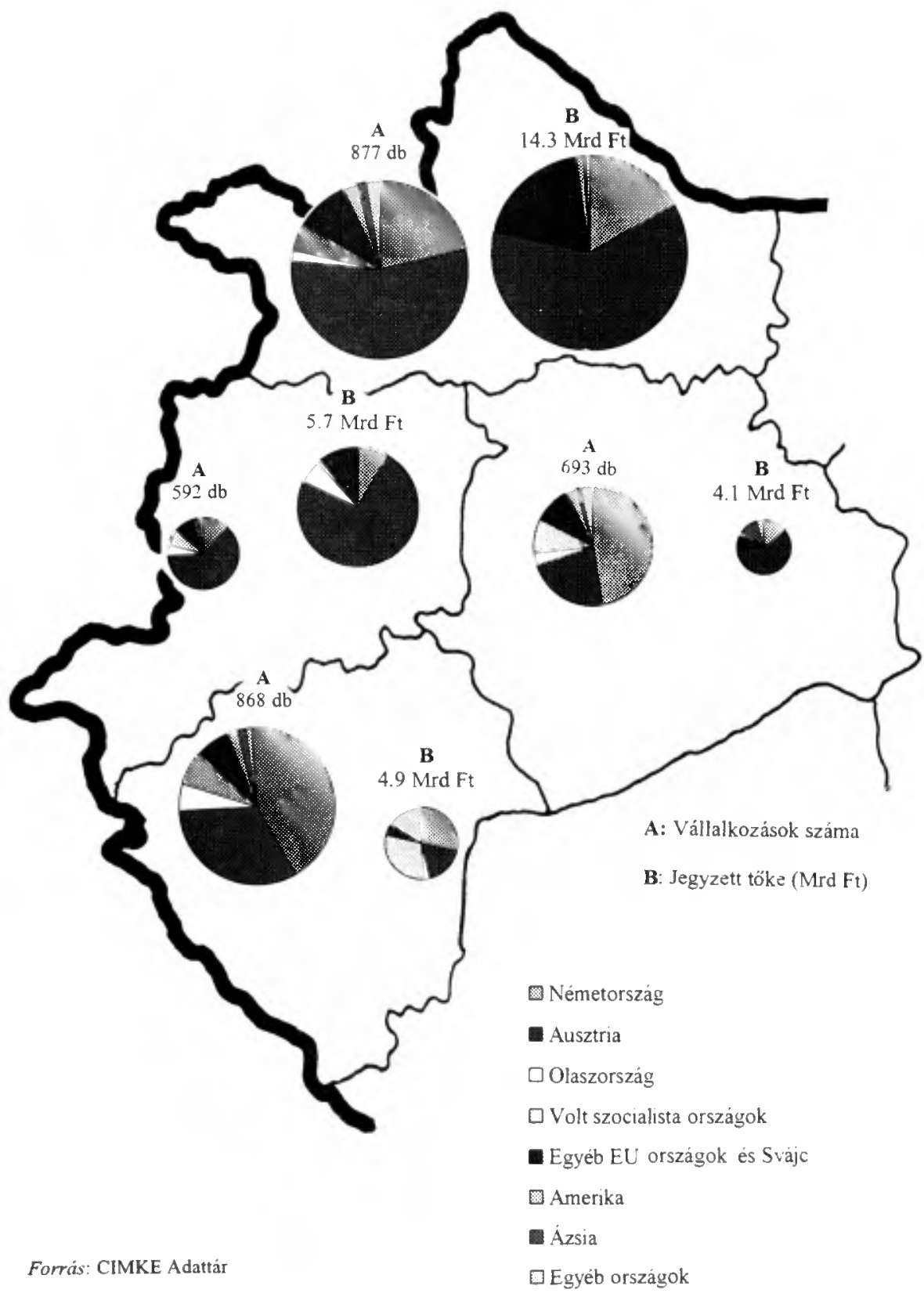


A külföldi töke aktivitása a térségben számottevö, annak megyéi között viszont kimutatható különbségek vannak. A kilencvenes évek elejét jellemzö nagy tökeimport, ami együttjárt a privatizációban való határozott külföldi részvétellel, az évtized közepére már mérséklödött. A szomszédos Ausztria befektetöinek országosan kedvelt térségében napjainkban már inkább a kis és a közepes tőkeállományok jelennek meg nagyobb számú szervezetben, $s$ a gazdaság egyre több ágazatában. A németországi befektetésekre alapvetöen a nagyobb tökeállomány jellemzö, amelyek egy-egy térségi, de országosan is meghatározó gazdasági szervezetben realizálódtak, részben új beruházások formájában, részben pedig az állami vagyon privatizációjában való, meghatározó részvétellel.

\section{A külgazdasági orientáció}

A térség négy megyéjének külkereskedelmi forgalmát élénk dinamika jellemzi, hiszen 1991 és 1994 között az export 150,9\%-kal növekedett, míg az import 143,7\%-kal. A kiegyenlitett növekedés azonban jelentős export többlettel járt együtt mindkét esztendőben, tehát a térség kiszállításai tartósan meghaladják a beszállításokat, amely gazdaságának erőteljes külgazdasági orientációját tükrözi.

A külkereskedelmi kapcsolatok intenzitása természetesen különböző a megyék között, hiszen egyértelmú sorrend állítható fel a korábban jelzett gazdasági potenciál alapján, azaz Györ-Moson-Sopron, Vas, Veszprém és Zala megye követi egymást mind az export, mind az import forgalomban. Közöttük a különbség tartósnak mondható, ugyan a forgalmi dinamikák eltéröek, látványos a növekedés Györ-Moson-Sopron megyében, viszont visszafogott, a térség összes forgalma emelkedésének ütemét már nem éri el Zala megye gazdasága.

A külkereskedelmi forgalom területi koncentrációja egyértelműen tükrözi a gazdaság térségi eloszlását Györ-Moson-Sopron megyében. Győr és Sopron részesedése kiugró, egyben az elöbbi központ a térségi szintü külkereskedelem centrumának is tekinthető, hiszen mindkét relációból a forgalom közel 20-20\%-a itt realizálódik. Vas megyében Szombathely szinte az egyedüli meghatározó település a külgazdasági kapcsolatokban, míg Zala megyében a két nagyváros a forgalom egyre nagyobb hányadát koncentrálja. Veszprém megye gazdaságában a megyeszékhely szerepe nem domináns, igy ott a területi koncentráció polarizáltabb, hiszen Pápa, Füzfó és Várpalota az exportban megelözi a megyeszékhelyet, viszont a beszállításokban a vezető szerepet Veszprém már a megyében megtartja.

A megyeszékhelyek és a két nagyváros mellett a térségben a külkereskedelmi kapcsolatok terjedését jól szemlélteti azon települések száma, illetve annak változása, ahol a lokális vállalkozások külső piaci együttmüködést mutatnak fel (5. táblảzat).

A gazdasági szervezetek dinamikus terjedését illusztrálja, hogy a vizsgált két időpontban a régióban a települések közel 40\%-ában valamilyen szintü külkereskedelmi tevékenységet folytató vállalkozások müködtek.

A régió külkereskedelmi forgalmának alakulásán túl annak áttekintése is lényeges, hogy milyen országokkal, országcsoportokkal áll kapcsolatban a térség gazdasága. A gazdasági kapcsolatok meghatározó irányát Németország képviseli mindkét relációban és mindegyik területi egységnél. Térségi szinten az exportban a 
németországi szállitások az 1991. évi 29,2\%-ról 1994-re 36,1\%-ra növekedtek, míg a beszállításoknál 34,4\%-ról - az elözōnél kisebb mértékben - 37,7\%-ra. A németországi kapcsolatok dinamikája látványos, hiszen a más országokból vagy országcsoportokból történő beszerzések és értékesítések részesedése térségi szinten csökkent, ebben talán az osztrák külkereskedelmi forgalom visszaesése a legszembetünőbb (export: 1991-22,1\%, 1994-16,9\%; import: 1991-29,8\%, 1994$22,2 \%$ ). Egyedül Olaszország javította kisebb mértékben az import vonatkozásában a helyzetét a térségben (1991 6,6\%, 1994 8,5\%), illetve a kisebb országok közül (a forgalom 3\%-át meg nem haladó) Szlovákia küzdötte fel magát a büvös határ közelébe (1994 2,9\%).

\section{TÁBLÁZAT}

Külkereskedelmi kapcsolatokkal rendelkezö települések száma a régióban

Number of settlements with external trade in teh region

\begin{tabular}{|l|c|c|c|c|c|c|}
\hline \multicolumn{1}{|c|}{ Megye } & \multicolumn{4}{c|}{1991} & \multicolumn{3}{c|}{1994} \\
\hline & export & import & $\begin{array}{c}\text { település arány } \\
(\%)\end{array}$ & export & import & $\begin{array}{c}\text { település arány } \\
(\%)\end{array}$ \\
\hline Györ-M.-S. & 55 & 66 & 38,2 & 69 & 94 & 54,3 \\
\hline Vas & 41 & 46 & 21,3 & 56 & 61 & 28,2 \\
\hline Veszprém & 57 & 78 & 35,1 & 70 & 97 & 43,5 \\
\hline Zala & 40 & 54 & 21,0 & 65 & 80 & 31,1 \\
\hline Régió ossszesen & 193 & 244 & 28,1 & 260 & 332 & 38,2 \\
\hline
\end{tabular}

Forrás: Az Északnyugat-Dunántúl területfejlesztési stratégiája, 1995.

A német gazdaság jelenléte és befolyása a térségben tehát egyértelmü, ezt illusztrálja a 6. táblázat, amelyben részletesen mutatjuk be a forgalom alakulását, annak arányát, s egyenlegét. Látható, hogy míg 1991-ben a két reláció különbözete pozitív volt mindegyik megyében, addig 1994-re már a kisebb külkereskedelmi forgalmat mutató megyékben beszállítási többlet jelentkezett, azaz az export látványos visszaesése tapasztalható, miközben például Veszprém megyében az import erőteljes növekedése volt megfigyelhető. Vas megye gazdasága az ott müködö néhány jelentős - autóipar, gépipar, textilruházat - német érdekeltségü vállalkozás miatt erösen kötödik a német gazdasági térhez, Győr-Moson-Sopron megye esetében ez a függöség már kisebb, de összességében számottevő, meghatározó.

A megyeszékhelyek, illetve a gazdasági erőforrásokat koncentráló nagyvárosokban 1994-ben a német gazdasági kapcsolatok szinte minden esetben az első helyen szerepeltek (7. táblázat).

A német gazdaság tehát a térség külkereskedelmi kapcsolataiban jelentös szerepet játszik, a gazdasági szervezetek beszerzéseiknek és értékesítéseiknek meghatározó iránya Németország, így ezen ország gazdaságának bármilyen irányú változása 


\section{Rechnitzer János:}

Az Északnyugat-Dunántúl térségének gazdasági adottságai és versenyelőnyei Tér és Társadalom, 11. 1997. 1. 1-38. $p$.

erősen befolyásolja a térség egészének és annak domináns gazdasági centrumainak mükődését és egyben fejlődését is.

\section{TÁBLÁZAT}

Az Északnyugat-Dunántúl megyéinek külkereskedelmi forgalma Németországga,l

1991, 1994 (E USD)

Turnover of the Nortwest Transdanubian counties' trade with Germany

1991, 1994 (thousand USD)

\begin{tabular}{|c|c|c|c|c|c|c|c|c|c|}
\hline \multicolumn{8}{|c|}{1991} & & \\
\hline & \multicolumn{3}{|c|}{ Export } & \multicolumn{3}{|c|}{ Import } & \multirow[t]{2}{*}{ Egyenleg } & & \\
\hline Megyék & (a) & (b) & (c) & (a) & (b) & (c) & & & \\
\hline Györ-M.-S. & 119401,1 & $37,1 \%$ & $30,5 \%$ & 122325,9 & $41,6 \%$ & $37,7 \%$ & $-2924,8$ & & \\
\hline Vas & 73082,7 & $22,7 \%$ & $27,4 \%$ & 86669,2 & $29,5 \%$ & $35,3 \%$ & $-13586,5$ & & \\
\hline Veszprém & 68931,2 & $21,4 \%$ & $27,2 \%$ & 44737,0 & $15,2 \%$ & $31,7 \%$ & 24194,2 & & \\
\hline Zala & 60725,7 & $18,9 \%$ & $31,5 \%$ & 40039,6 & $13,6 \%$ & $28,3 \%$ & 20686,1 & & \\
\hline Térség ósszesen: & 322140,7 & $100,0 \%$ & & 293771,7 & $100,0 \%$ & & 28369,0 & & \\
\hline \multicolumn{8}{|c|}{1994} & \multicolumn{2}{|c|}{ Változás mértéke } \\
\hline & \multicolumn{3}{|c|}{ Export } & \multicolumn{3}{|c|}{ Import } & Egyenleg & \multicolumn{2}{|c|}{$1994 / 1991(\%)$} \\
\hline Megyék & (a) & (b) & (c) & (a) & (b) & (c) & & Export & Import \\
\hline Gyỏr-M.-S & 211258,7 & $35,1 \%$ & $32,8 \%$ & 166062,6 & $35,9 \%$ & $34,2 \%$ & 45196,1 & 176,9 & 135,8 \\
\hline Vas & 206792,2 & $34,4 \%$ & $45,1 \%$ & 166062,4 & $35,9 \%$ & $44,1 \%$ & 40729,8 & 283,0 & 191,6 \\
\hline Veszprém & 90236,4 & $15,0 \%$ & $29,8 \%$ & 63977,8 & $13,8 \%$ & $33,4 \%$ & 26258,6 & 130,9 & 143,0 \\
\hline Zala & 93205,1 & $15,5 \%$ & $35,8 \%$ & 66285,0 & $14,3 \%$ & $38,7 \%$ & 26920,1 & 153,5 & 165,5 \\
\hline Régió osszzesen: & 601492,4 & $100,0 \%$ & & 462387,8 & $100,0 \%$ & & 139104,6 & 186,7 & 157,4 \\
\hline
\end{tabular}

(a) Összeg (E USD)

(b) Részesedés a térségben (\%)

(c) Részesedés a megyében (\%)

Forrás: Az Északnyugat-Dunántúl területfejlesztési stratégiája 1995.

A térség összes importjából a német import aránya 1991 -ben 34,4\%, 1994-ben 37,7\%.

A térség összes exportjából a német export aránya 1991-ben 29,2\%, 1994-ben 36,1\%.

A térség osszzes importjából a német import aránya 1991-ben 34,4\%, 1994-ben 37,7\%.

Az export változása (1994/1991) 123,6\%, az import változása (1994/1991) 109,6\%.

\section{TÁBLÁZAT}

A német gazdaság súlya a régió nagyvárosaiban

The weight og the German economy in the big cities og the region

\begin{tabular}{|l|cc|cc|}
\hline \multicolumn{1}{|c|}{ Város } & \multicolumn{2}{c|}{ Export } & Import \\
\hline Györ & $2 . ;$ & $45,4 \mathrm{~m}$ USD $(13,7 \%)$ & $1 . ;$ & $62,7 \mathrm{~m} \mathrm{USD}(28,2 \%)$ \\
\hline Sopron & $1 . ;$ & $40,5 \mathrm{~m}$ USD $(60,3 \%)$ & $2 . ;$ & $22,9 \mathrm{~m} \operatorname{USD}(30,1 \%)$ \\
\hline Szombathely & $1 . ;$ & $147,0 \mathrm{~m}$ USD $(58,9 \%)$ & $1 . ;$ & $116,9 \mathrm{~m} \operatorname{USD}(57,3 \%)$ \\
\hline Veszprém & $1 . ;$ & $20,8 \mathrm{~m}$ USD $(51,9 \%)$ & $1 . ;$ & $16,3 \mathrm{~m} \mathrm{USD}(35,4 \%)$ \\
\hline Zalaegerszeg & $1 . ;$ & $33,0 \mathrm{~m}$ USD $(28,2 \%)$ & $1 . ; \quad 18,5 \mathrm{~m} \mathrm{USD}(27,5 \%)$ \\
\hline Nagykanizsa & $2 . ;$ & $11,9 \mathrm{~m}$ USD $(19,9 \%)$ & $1 . ; \quad 12,8 \mathrm{~m} \mathrm{USD}(33,8 \%)$ \\
\hline
\end{tabular}

Forrás: Az Északnyugat-Dunántúl területfejlesztési stratégiája, 1995. 


\section{A foglalkoztatás}

A térség gazdasági szerkezetének átalakulását és modernizációját a foglalkoztatási struktúra változása jellemezheti. Azt kívánjuk illusztrálni, hogy egyrészt a mezőgazdasági szektor miként szorul vissza, másodszor, milyen intenzitással csökken az ipari foglalkoztatottak aránya, végül a szolgáltató ágazatban és annak egyes tevékenységi csoportjában miként bővül a munkahelyek száma.

A 8. táblázatból egyértelmủen kiderül, hogy a térségben és annak minden megyéjében a mezőgazdasági foglalkoztatottak aránya 1992 és 1993 között csökkent több, mint 10 ezer fôvel (22,3\%). Hasonlót tapasztalhatunk az iparban dolgozóknál is, azonban itt közel 16 ezer fös a csökkenés $(8,6 \%)$, ami viszont nem befolyásolta a foglalkoztatás szerkezetét. Megyék közötti különbséget nem tapasztaltunk az ipari munkaerő mérséklésében, a legnagyobb volt Györ-MosonSopron megyében ( 5322 fö, 9.2\%), s a legkisebb Vas megyében (2016 fö, 5,3\%).

Azt regisztrálhatjuk, hogy a szolgáltató ágazat lassú felszivója, befogadója az ütemesen leépuuloó vagy pontosabban, átstrukturálódó (hiszen a foglalkoztatottak száma 8,2\%-kal csökkent) munkaerönek.

A térség egyes megyéiben a gazdaság fejlettségi fokának függvényében - vagy a tercier funkciók terjedése ütemében - nö a szolgáltatási szektorban foglalkoztatottak aránya, igy sorrendben Veszprémben 44,5\%-ról 47,8\%-ra, Zalában 43,8\%-ról 46,3\%-ra, Györ-Moson-Sopron megyében 45,1\%-ról 47,1\%-ra és Vasban 45,3\%ról 45,5\%-ra, ami együttesen térségi szinten 44,7\%-ról 46,8\%-ot jelent a tercier szektor javára.

A szolgáltató ágazatok közül a klasszikus szolgáltatásokban, így a kereskedelemben, a szállításban, valamint a szálláshely és vendéglátásban dolgozók magas arányt képviselnek. Ezekben az ágazatokban is a létszám csökkenése figyelhetö meg, annak üteme valamelyest meghaladja $(9,1 \%)$ az ipari létszám mérséklését. Mindez arra utal, hogy az ágazatcsoportban jelentős átalakulások zajlanak. Így a privatizáció hatására megindult a kereskedelmi hálózatok átépítése, azok koncentrációja és egykori irányító egységeik felszámolása vagy például a szállítási ágazatban is számos kis- és középvállalkozás megjelenésével változnak a foglalkoztatási arányok. A szálláshely szolgáltatás és a vendéglátás ágazatban viszont a térség megyéi között különbségeket tapasztalunk. Zala megyében nött a foglalkoztatottak száma közel 10\%-kal, Győr-Moson-Sopron megyében stabilizálódott, azaz csak jelentéktelen mértékben csökkent (3,5\%), de Vasban ( $10,4 \%)$ és Veszprémben $(18,9 \%)$ már eröteljesebben.

A gazdasági és az üzleti szolgáltatásokban, mint a modern gazdaság egyik fontos képviselöjében térség szinten a foglalkoztatottak aránya nem magas, hiszen a 33,2\% szint csak jelzés értékkel mutatja, hogy ezen tevékenységek már jelen vannak a megyék gazdaságában.

Persze, ha keressük az okait annak, hogy ezen modern gazdasági és üzleti szolgáltatásokban foglalkoztatottak aránya miért olyan alacsony a megyékben, arra több magyarázatot adhatunk. Az egyik a szervezeti rendszerben keresendö, abban, hogy a gazdasági egységekböl a jelentősebb munkahelyt kinálók, így például a bankok, biztosító intézetek vagy a különféle befektetési társaságok nem megyei 


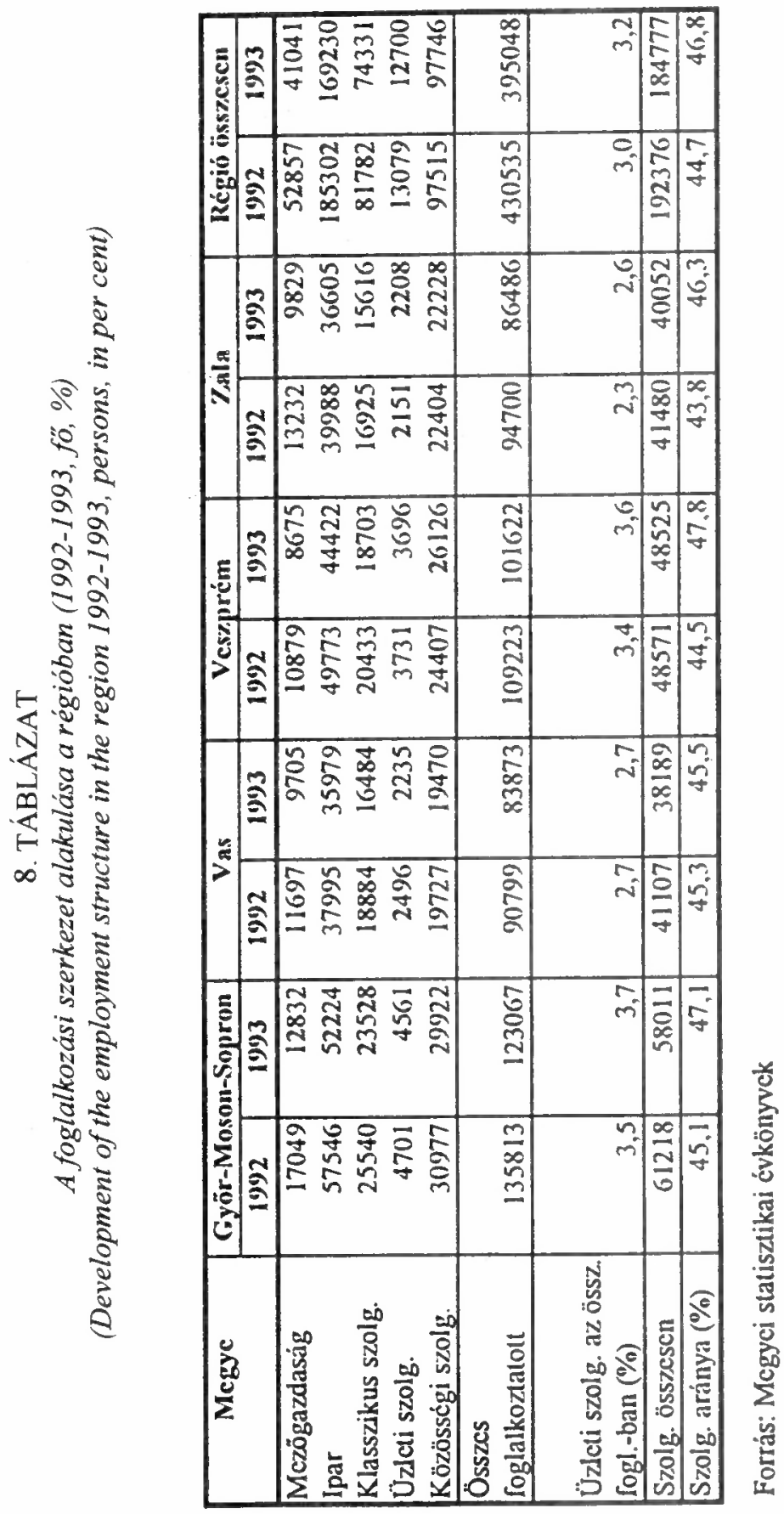


székhelyüek, azoknak a központja Budapesten található, így a regisztrációban is a fövárosi központ szerepel. Másrészt ugyan számos szervezet foglalkozik üzleti és pénzügyi szolgáltatásokkal, mint azt a 9. táblázat mutatja, azonban ezek kimondottan kisvállalkozások, alacsony létszámmal (több, mint 95\%-uk a 21 fó alatti létszám kategóriába tartozik), tevékenységüket számosan nem is föállásban, hanem kiegészitő tevékenységként végzik, s végül a vállalkozások bejegyzésekor a tevékenységi területek tömegét jelölik meg, így nem egyértelmú, hogy valójában mivel foglalkoznak, mire specializálódnak.

Ha áttekintjük a kimondottan pénzügyi, fejlett üzleti és gazdasági szolgáltatást is végző szervezeteket, illetve az azok által megnevezett tevékenységek ${ }^{8}$ területi eloszlását a térségben, akkor egyértelınüen kitünik, hogy kevés kivételtől eltekintve a térség városaiban, sőt többségükben a nagyközpontokban koncentrálódtak, oda települtek. Ennek oka érthető, hiszen a megyeszékhelyeken, illetve a nagy- és középvárosokban találnak piacot és üzleti kapcsolatokat, itt áll rendelkezésre az a képzett munkaerő, aki ezen szolgáltatásokat el tudja végezni, le tudja bonyolítani, de éppen a nagyobb centrumok kínálják azt az infrastruktúrát is, aminek igénybevétele szükséges az üzleti kapcsolatok szervezéséhez. A modern szolgáltatások telepitésének általános trendje egyértelmüen a nagyvárosokhoz kapcsolódik. A probléma az, hogy miként érhetök el ezek a centrumok, milyen lehetösége van a vállalkozásoknak, a személyeknek ezek igénybevételére, azaz a mindennapi gazdasági tevékenységükbe ezek kínálatát hogyan tudják integrálni. Valójában a kommunikációs rendszerek fejlettségével kapcsolható össze a modern szolgáltatások igénybevétele, miközben azok terjedésével már az új szükségletek is megjelennek, ami aztán a gazdasági aktivitás fokozását eredményezheti.

\section{TÁBLÁZAT}

A gazdasági és üzleti szolgáltatást folytató jogi személyiségü szervezetek száma a térség megyéiben, 1993 (db)

Number of organisations with legal entities with economic and business service activity in the counties of the region, 1993 (No.)

\begin{tabular}{|l|c|c|c|c|c|}
\hline \multicolumn{1}{|c|}{ Szolgáltatások } & $\begin{array}{c}\text { Györ- M.- } \\
\text { S. }\end{array}$ & Vas & $\begin{array}{c}\text { Veszpré } \\
\mathrm{m}\end{array}$ & Zala & $\begin{array}{c}\text { Térség } \\
\text { összesen }\end{array}$ \\
\hline Pénzügyi tevékenység. & 26 & 11 & 19 & 25 & 81 \\
\hline Ingatlan és egyéb szolgáltatás & 540 & 215 & 412 & 282 & 1449 \\
\hline Üzleti szolgáltatás összesen & 566 & 226 & 431 & 307 & 1530 \\
\hline Aránya az ósszes szervezetben (\%) & 18,5 & 15,2 & 18,9 & 17,9 & 17,9 \\
\hline
\end{tabular}

Forrás: CIM-KE adatbázis. KSH. 1993.

A térség egészében a közösségi szolgáltatásokban foglalkoztatottak száma nem változott, így aránya a csökkenő összes létszámon belül nött (22,6\%-ról 24,7\%-ra). Általános irány a térség megyéiben, hogy mindenütt emelkedik a közigazgatásban, kötelező társadalombiztosításban dolgozók száma, az oktatásban foglalkoztatottak száma változatlan vagy kisebb mértékben emelkedett (Zala és Veszprém megye), míg az egészségügyi szolgáltatásokban a megyék többségében csökkenést tapasztalunk, csak Veszprém megyében emelkedett néhány százalékponttal. Végül 
az egyéb társadalmi és közösségi, személyi szolgáltatásokban is - éppen Veszprém megyét kivéve - kismérvü csökkenést regisztrálhatunk.

A közösségi tevékenységekhez kapcsolódó szektorokban - véleményünk szerint már rövid távon változás áll be a foglalkoztatásban. Felismerhetö, hogy a központi kormányzat ki kíván vonulni a széles skálát átfogó szociális rendszerekból és azokban nagyobb teret szándékozik adni a magángazdaságnak. Miközben az önkormányzatok is arra kényszerülnek - részben a gazdasági kényszerek miatt, részben bizonyos területeken az ellátási szükségletek visszaesése (népesség szám csökkenése) következtében -, hogy mérsékeljék a közösségi szolgáltatások támogatását.

Megkezdődött a nagy állami szociális rendszerek átalakitása, azok szerkezetének megújitása, ami szükségszerüen létszám leépitéssel jár egyuitt, melyet a magánszféra éppen a kimondottan racionális gazdasági szempontjai miatt, nem fog teljes mértékben felvenni. Várható tehát, hogy a térség, de a megyék szintjén is a szolgáltató szektorok közül a közösségi szolgáltatásokban munkahelyek szünnek meg, ami a foglalkoztatási feszültségek növelését eredményezheti.

A munkaerőpiac keresleti és kínálati oldalának megbomlása az ország térségi közúl az Északnyugat-Dunántúlon következett be a legkésőbben. Állománycsoportonként eltérő időben ugyan, de 1990 végére az országos, a térség és annak megyei munkaerőpiacain is - máig érvényesen - a kínálat meghaladta a keresletet. A piac megbomlása elöször a segédmunkát keresőknél (Zalában, Vasban már 1989-ben, Györ-Moson-Sopron és Veszprém megyében 1990 év elején) következett be. Öket követte egymással párhuzamosan a betanított, illetve szakmunkások munkaerőpiacának kínálati helyzetböl keresleti piacba történö átfordulása. Időben az események a négy megyében egymást követték, 1990. szeptemberében Veszprém megyében, októberben Zala, novemberben Vas, decemberben Györ-Moson-Sopron megyében alakult ki a munkahely-hiányos helyzet.

Északnyugat-Dunántúl foglalkoztatási helyzete az elmúlt évben folyamatosan a térségek közül - a fövárost nem számítva - a legkedvezőbb képet mutatta. A térség egésze és a megyék külön-külön is az országos értékeknél jóval kedvezőbb foglalkoztatási helyzetben voltak az elmúlt években. A négy megyéböl, ahol a munkanélküliség aránya soha sem lépte túl a kritikusnak nevezhetö 10\%-os munkanélküliségi értéket, három (Györ-Moson-Sopron, Zala, Vas) ebben a térségben található. A térséghez tartozó Veszprém megyében a munkanélküliség mértéke elsősorban a szerkezetváltásban érintett iparágak miatt súlyosabb volt a térség átlagánál, de még így sem közelítette meg a megyék átlagát.

$\mathrm{Az}$ északnyugat-dunántúli megyékben a munkanélküliség tartósan a még elfogadható, kezelhető szinten maradt. Ez a térség relatíve fejlett gazdasága mellett, köszönhető a korszerübb gazdasági struktúrának, a kedvezöbb piacváltási feltételeknek, a megyék fejlett humán erőforrásainak, az iskolázottság, szakképzettség, innovációs ismeretek szempontjából az ország más térségeivel szemben meglévő előnyének.

Azonos gazdasági problémák, pl. keleti piacok elvesztése ebben a térségben különösen az országhatár menti megyékben - kisebb megrázkódtatást jelentett - az átállás rugalmassága miatt - mint más megyékben, térségekben. 
A térség relative kedvezöbb foglalkoztatási helyzetében szerepe van a szomszédos országok Ausztria, Szlovénia és részben Szlovákia piacának és az ott szerzett munkavállalói tapasztalatoknak, általában a fejlett térségek közelségének.

Az alacsony szintü munkanélküliség (10. táblázat) és a regisztrált munkanélküliek viszonylag kedvező összetétele ellenére aggasztó a térségben az üres álláshelyek számának - különösen a kedvezőbb munkanélküliségi helyzetben lévő megyékben tartósan alacsony szintje. Ez a tény - egy esetleg alacsony színvonalú állami álláshely feltárás esetén is - a jövöre nézve kedvezötlen elöjelnek tekinthetö.

\section{TÁBLÁZAT \\ A munkanélküliség alakulása az Északnyıgat-Dunántúl megyéiben 1990-1995, (\%)}

Development of unemployment in the Northi'est Transdanubian counties (1990-1995, in per cent)

\begin{tabular}{|l|c|c|c|c|c|}
\hline \multicolumn{1}{|c|}{ Idöpont } & Györ-Moson-Sopron & Vas & Veszprém & Zala & Ország összesen \\
\hline 1990. június & 0,4 & 0,4 & 0,7 & 0,8 & 0,9 \\
\hline 1990. december & 1,0 & 0,6 & 1,6 & 1,4 & 1,7 \\
\hline 1991. június & 2,1 & 2,2 & 3,7 & 3,3 & 3,9 \\
\hline 1991. december & 5,7 & 5,9 & 9,0 & 6,8 & 8,5 \\
\hline 1992. június & 6,9 & 7,2 & 9,5 & 7,4 & 10,1 \\
\hline 1992. december & 8,0 & 8,4 & 11,7 & 9,3 & 12,3 \\
\hline 1993. június & 8,1 & 8,6 & 11.5 & 9,8 & 12,6 \\
\hline 1993. december & 7,8 & 8,8 & 11.5 & 9,9 & 12,1 \\
\hline 1994. június & 7,5 & 8,0 & 10,0 & 9,3 & 11,0 \\
\hline 1994. december & 6,9 & 7,3 & 10,3 & 9,1 & 10,4 \\
\hline 1995. június & 6,2 & 6,6 & 8,9 & 8,2 & 10,1 \\
\hline
\end{tabular}

Forrás: Az Északnyugat-Dunántúl területfejlesztési stratégiája, 1995.

\section{A térség versenyképessége országos összehasonlitásban}

A megyék a gazdasági erőforrásokért versenyt folytatnak. Ez a verseny lehet tudatos és irányított, de lehet kimondottan regisztráló jellegü is. Az elöbbi esetben az adott megye különféle - politikai, gazdasági, intézményi - szereplöi egy összehangolt akciósorozattal kísérlik meg megteremteni azokat a feltételeket, amelyek a gazdaság előrevivő szektorainak vagy annak bizonyos szegmenseinek a megtelepedését és múködését szolgálják. A másik esetben inkább csak regisztrálják a folyamatokat, figyelemmel kisérik helyzetüket a gazdasági felszereltség, ellátottság alapján és megállapítják elmozdulásukat egyik időszakról a másikra.

Nem egyszerü olyan mutatókat kidolgozni, amelyek a megyék gazdasági versenyképességét tükrözik. Egyrészt nem könnyü szakmailag meghatározni, hogy mely faktorokhoz kötödnek a versenyképesség kategóriái. Ezek döntően a modern gazdasági tevékenységeket éppen úgy tartalmazhatják, mint az ottani gazdasági egységek teljesilményét, annak szerkezetét, valamint az adott térség, térség beruházási és fejlesztési aktivitását. Másrészt a versenyképességet kifejezö tényezöknek az íỏbeli változásokat is tükröznie kell, azaz képviseljenek valamiféle 
dinamikát, fejezzék ki a struktúra változásának, átalakulásának jellegét vagy legalábbis annak az elmozdulási lehetöségeire is adjanak eligazítást. Harmadszor ezek a versenyképességet kifejező mutatók jól elérhetök legyenek, azoknak az egyik időszakról a másikra történő összeállíthatóságával a változások, az elmozdulások mértéke, annak hordozói egyértelmüen regisztrálást nyerjenek. S végủl a mutatók valahol közelítsenek az Európai Unió által elfogadott, regionális fejlettséget kifejezö paraméterekhez, hogy ezzel a megyék, térségek állapota nemzetközi összehasonlitásban is megragadható legyen.

A fenti elveket - többé-kevésbé - figyelembe véve kíséreltük meg összeállitani a megyék versenyképességének mutatóit, amelyet három csoportba rendszereztünk és mindegyik csoportot külön-külön vizsgáljuk, hogy a térség, de egyben az ország egészének gazdaságáról is átfogó képet kapjunk?

\subsection{A gazdaság teljesitménye}

Az első csoport a gazdaság teljesítményét illusztrálja, de erőteljesen kapcsolódik a magyar gazdasági szerkezethez, amiben még az ipari termelés a meghatározó, a domináns. Az induló mutató a megyei GDP mértéke egy lakosra vetítve. A mutató az EU norma szerint is elfogadott és alkalmazott területi fejlettségi paraméter, amelyet Magyarországon elsőként 1994-re állapítottak meg megyei bontásban. A területi gazdaság aktivitásának egyik fokméröje a beruházások alakulása egy lakosra vetítve. Ebben a mutatóban egyértelmúen megjelenik a területi-gazdasági potenciál éppen úgy, mint a térség és annak gazdasága iránti érdeklödés, a regionális piac vonzása, sőt a lokátis-regionális gazdaság aktivitása is. A gazdasági szerkezet-átalakítás területi sikerét vagy sikertelenségét tükrözheti a munkanélküliségi ráta. Hiszen annak szintje éppen azt jelzi, hogy milyen gyorsan és milyen arányban állt át a területi gazdaság, illetve érzékelteti a munkaerö-állomány felkészültségét az új tevékenységek fogadására vagy éppen a korábban említett tőkeérdeklődést a gazdaság iránt, annak megújitására, átalakítására. Végül ebben a blokkban tüntettük fel az export arányát az ipari értékesítésben, amely a megyék iparának külpiaci megítélését jeleníti meg.

$\mathrm{Az}$ egyes tényezők között nem tettünk különbséget, azaz mindegyiket azonosan egyenló súllyal szerepeltettük az összevetésnél, hiszen roppant nehéz megítélni azt, hogy az adott tényezők közull melyik, milyen arányban alakítja a területi gazdaságot, annak jellegét miként befolyásolja.

A gazdaság teljesítménye (5.ábra) alapján az országban határozottan kitapintható különbségek húzódnak meg, hiszen a nyugat-keleti törésvonal mellett az észak-déli különbségek is kitünnek. Az Északnyugat-Dunántúl térsége megosztott, hiszen Győr-Moson-Sopron megye - a fövárossal egyưtt - minden tényezö vonatkozásában jelentős fejlödést mutat. Vas megye a második kategóriába került, amelyre a dinamikát mutató, az gazdasági átalakulást látványosan folytató térségek sajátosságai vonatkoznak (magas GDP és exportteljesítmény, egyben mérsékelt munkanélküliség, de beruházási teljesítmények időbeli változásának dinamikája országos átlag alatt alakult). Zala és Veszprém megye a mérsékelt teljesítményt nyújtó megyék csoportjába sorolódott, ahol lényegében a szerkezeti változások még nem fejezödtek be, mondhatni azok csupán megkezdődtek, de az elmozdulások 


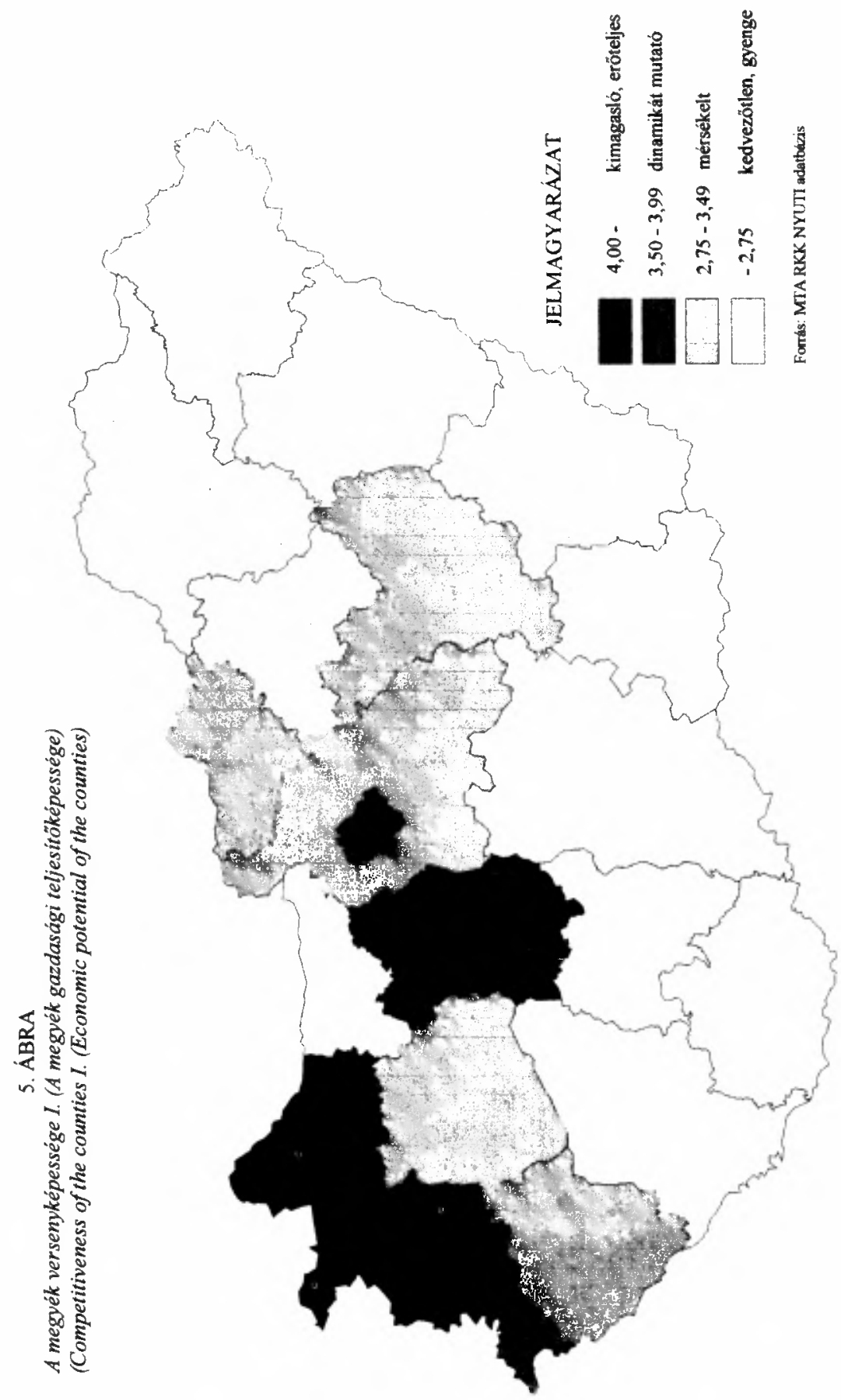


biztató jegyeket mutat (átlagos GDP, növekvő beruházási teljesítmények, még feszültségek a foglalkoztatásban, de átlagosnál nagyobb ipari export teljesítmény).

Fejér megye gazdasági teljesítményében azonos jegyeket mutat a Vas megyével, így lényégében szervesen illeszkedik az Északnyugat-Dunántúl térségéhez, hiszen egy nagyobb dinamikát, gyorsabb gazdasági fejlődést reprezentál a számottevő beruházási teljesítménnyel és az ipari exporttal.

$\mathrm{Az}$ ország többi részében a gazdaság teljesítménye ezen mutatók alapján mérsékelt, talán a térségünkön kívül Pest (kedvezö beruházási ráta és munkanélküliség), Nógrád (magas beruházási teljesítmény és ipari export) és JászNagykun-Szolnok megye (átlag körüli beruházási teljesítmény és ipari export) jelez valamiféle elmozdulást, így vélhetően - ugyan más-más mutatók vonatkozásában ezekben a megyékben is megkezdődött a gazdasági szerkezet átalakulása, hasonlóan Zala és Veszprém megyéhez.

\subsection{A gazdaság fejlesztési adottságai}

A térségek versenyképessége szempontjából meghatározó szereppel rendelkeznek azok a tényezők, amelyek egyrészt jelzik a gazdaság átállását az indusztriális szakaszról a posztindusztriális fejlödési pályára, másrészt érzékeltetik a gazdasági szereplök preferenciáit a teruleti egység iránt, amit a vállalkozások számával és a külföldi befektetések nagyságával jellemezhetünk, $s$ végül azokat a tényezőket, amik a megújitást képviselhetik, azaz az innovációs lehetőségekre, képességekre utalnak.

A modern gazdasági szektorok térnyerését jellemzi a szolgáltatás aktivitás, amit az 1000 lakosra jutó tercier szektorban foglalkoztatottak számával jellemzünk. Ez a mutató érzékelteti a területi gazdaság átalakulását, az új rendszerủ gazdasági szereplők megjelenését és térnyerését, a modernizáció elöretörését. Ezt finomítottuk azzal, hogy külön faktorként vizsgáltuk a modern üzleti szolgáltatásokban dolgozók arányát és a banki hálózatok sürüségét. A vállalkozás terjedése alatt az 1000 lakosra jutó jogi és nem jogi személyiségú gazdasági szervezetek számának változását értettük. A külföldi tőke jelenlétét, mint egy-egy megyének, annak gazdaságának és területi adottságának az elismertségét kifejező mutatót, az egy lakosra jutó külfơldi befektetések nagyságával jellemeztük. S végül fontos telepitési tényezönek tekintettük az innovációs potenciált, amit több mutatóból alakitottunk ki, így a szabadalmak számából, az egy fờre jutó KMÜFA támogatások ${ }^{10}$ mértékéből, a felsőoktatásban dolgozó oktatók, kutatók számából, a tudományos minősítettek ${ }^{11}$ számából, a $\mathrm{K}+\mathrm{F}$ vállalkozások számából.

A gazdaság fejlesztési adottságait illusztráló 6. ábráról egy nagyon megosztott térszerkezet rajzolódik ki, azaz az ország sokkal jobban tagolt, mint a gazdaság teljesitménye alapján, $\mathrm{s}$ az Északnyugat-Dunántúlon belül is számottevő kulönbségek mutathatók ki.

Az első megállapítás, hogy Budapest jelentősen, átlagon feluli értékeket mutat, azaz a főváros eröteljesen koncentrálja a modern gazdaságot megtestesító tényezőket, továbbá annak elfogadottsága, elismertsége, éppen a számottevő és az egész országra kiható piaca miatt, kimagasló. A kuloơnbség a föváros és a vidék között nagy, hiszen még a legjobb adottságokkal rendelkezó megye (Baranya) értéke is csak négyötöde Budapestnek, míg a legrosszabb helyzetben lévö megyéje (Nógrád) viszont háromszor kisebb a fövárosnál. 


\section{6. ÁBRA}

A megyék versenyképessége II. (A megyék fejlesztési lehetöségei) (Competitiveness of the counties II. (Development possibilities of the counties)
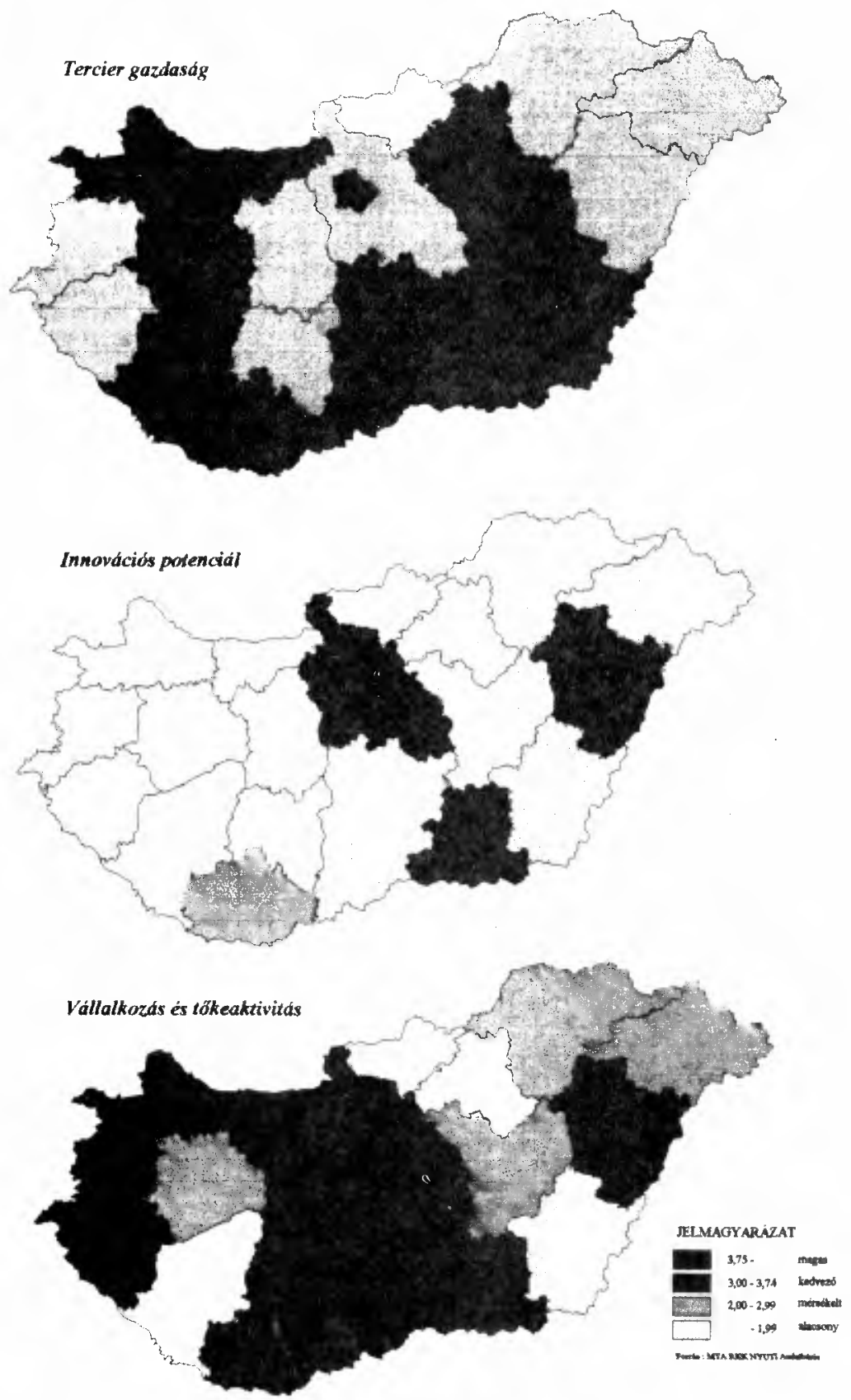
A második megállapítás, hogy az ország megosztott, azok a térségek, ahol a gazdaság teljesítménye magasabb, ott a piaci tényezőkhöz kapcsolódó faktorok jelenléte (szolgáltatások, vállalkozási aktivitás, külföldi tőke) jobban kimutatható, de karakteres térségek (régiók) még nem formálódnak ki.

A harmadik megállapítás, hogy a sajátos történelmi és településhálózati adottságok miatt élesen elválik az innovációs potenciál területi szerkezete a gazdaság teljesítményének és további fejlesztési adottságainak területi szerkezetétöl. Az egyetemi és kutató-fejlesztős helyeket tömörítö regionális centrumok megyéi közül csak Csongrád (Szeged) és Hajdú-Bihar (Debrecen) emelkedik ki, miközben ezeknek a megyéknek a gazdasági teljesítménye kimondottan visszafogott, mérsékelt.

A negyedik megállapítás, hogy az Északnyugat-Dunántúl megosztott a fejlesztési adottságok vonatkozásában. Egyedül Győr-Moson-Sopron megye emelkedik ki az országon és a térségen belül kedvező értékeivel, Veszprém megye erősen átlagos, míg Zala és Vas megye a tökeaktivitást kivéve, kedvezőtlen helyzetben van. Mindezek elgondolkodtatók a térség jövőjének szempontjából, hiszen belső erőforrásokra csak mérsékelten lehet támaszkodni, így a térség kitettsége növekszik, annak fejlődése a külső tényezóktől - külföldi befektetők, kormányzati támogatások, nemzetközi programok - függ. Természetesen éppen a rendelkezésre álló erőforrások jobb, összehangoltabb felhasználásával, közös fejlesztési célok kijelölésével, a források koncentrált hasznosításával és a regionális érdekek határozottabb megjelenítésével lehet formálni a térséget, bővíteni a fejlesztési lehetôségeket.

\subsection{A telepitési tényezök}

A gazdasági egységek számára lényeges, hogy egy-egy térség milyen feltételeket kínál a letelepedéshez, ezek a faktorok magának a gazdasági szervezeteknek a múködési, termelési, tevékenységi, feltételeit mennyiben segítik vagy éppen akadályozzák. A telepitési tényezók jellege, azok kínálata egyben versenyhelyzetet is teremt a térségek között, hiszen azok szerkezete változik, a gazdasági egységek igényei folyamatosan újabb és újabb elemekkel bővülnek, miközben a hangsúlyok eltolódnak, így térségek le, illetve felértékelődnek. Továbbá maguk a térségek adottságai is bövülnek, újabb és újabb kínálati elemekkel gyarapodnak, ami a vállalkozások vonzását fokozza, egyben növelve a versenyt azok megszerzéséért, letelepedéséért.

Tekintsük át a telepítési tényezők közül azokat az elemeket, amelyeket a tapasztalataink szerint a gazdasági egységek figyelembe vesznek, mérlegelnek a letelepedésnél és a tartós múködésnél. A tényezők számos elemet tartalmazhatnak, közőttük a súlypontok éppen az adott termelési és tevékenységi jellegek miatt más és más lehet, így természetesen egyedi, speciális döntések - amihez még számos gazdasági és nem gazdasági összetevő is számbevételre, értékelésre kerül - sorozata a vállalkozások helyének kiválasztásánál, meghatározásánál.

A telepítési tényezók ${ }^{12}$, azok rendszerezése, összevetése más térségekkel, összefoglaló helyzetértékelésre ad lehetőséget (7. ábra, 8. ábra). A térségben lévő gazdasági egységek és oda letelepedni szándékozók ebben a sokváltozós rendszerben fel tudják mérni helyzetüket, adottságaikat, így döntéseik biztonsága 


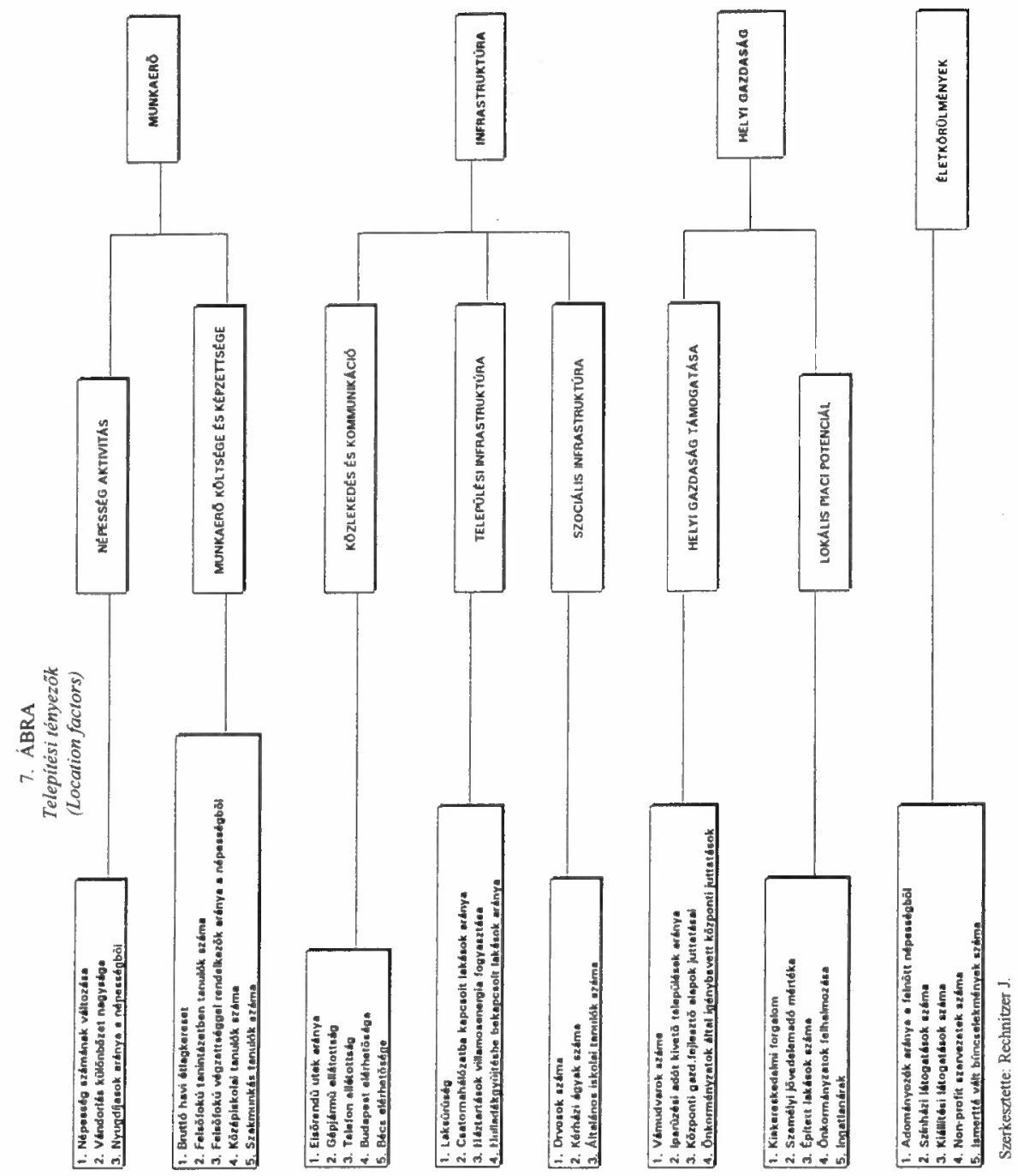


növekedhet. A térség és annak megyéinek irányító, az országos összevetésekkel bővített értékelése alapján, éppen a területfejlesztési koncepciójában jelölhetỏk ki azok az irányok, amelyek majd a telepítési tényezők jobbítását vagy éppen bỏvítését szolgálják.

A telepítési tényezők első csoportjában a népesség aktivitás elemzésénél vizsgáltuk a népesség számának változását (1990-1994), a területek népességfogadó és megtartóképességét, a vándorlási különbözet nagyságát (1980-1989), valamint a nyugdíjasok számát, ami a népesség aktivitását jellemzi.

A térség egységesnek mondható, hiszen az országosnál kedvezóbbek - éppen a jobb gazdasági helyzete miatt - a demográfiai paraméterek. A vándorlási kủlönbözet várhatóan tartósan pozitív marad, ami egyben növeli a térségben a fogyasztást, ugyanakkor nagyobb kínálatot és versenyhelyzetet teremt a munkaerópiacon, de valószínúleg a vállalkozások esetében is.

A munkaerő költségeit és képzettségét a havi bruttó bérek nagyságával, míg az utóbbihoz a népességen belül a felsőfokú végzettséggel rendelkezók arányát és a felsőoktatási intézményben tanuló hallgatók számát kapcsoltuk. A térség ebben a telepítési tényező csoportban már jobban megosztott. Györ-Moson-Sopron és Vas megye került az első csoportba, itt kedvezỏ feltételek biztosítottak a kvalifikált munkához, de a centrumokban már jelentős, képzett munkaerő-tartalék nincs. A térség másik két megyéje egységes képet mutat, telepítés szempontjából már elfogadhatónak tekinthető kategória alsó határát súrolják. A bérek valamivel alacsonyabbak ugyan, de a munkaerő képzettsége is mérsékeltebb, viszont nagyobb tartalékok állnak rendelkezése, még a centrum - jobban ellátott - településekben is.

A közlekedési és kommunikációs tényezők között öt elemet vizsgáltunk, így az elsörendű utak arányát az összes utakból, gépjármủ és telefon ellátottságot, valamint a fơváros és Bécs elérhetöségét. A térség úthálózatának mennyiségi és minōségi tényezői jóval elmaradnak a gazdaság teljesítményétől, hasonlóan kedvezőtlen még mindig a telefonellátottság, ugyan az országos átlag fölé került valamivel, de számottevő területi különbségek vannak a térségben, ami kimondottan rontja egyes mezotérségek, közép- és kisvárosok bekapcsolódását a gazdaság vérkeringésébe. A térség gazdasági centrumainak az elérhetősége a szomszédos európai nagyvárosokból és a fóvárosból elsősorban a földrajzi fekvés miatt kedvezó, ám az észak-déli közlekedési összeköttetések gyengék, sem mennyiségük, sem minőségük nem alkalmas a multiregionális kapcsolatok bővítésére, illetve az intraregionális együttmúködéseket is határozottan korlátozzák.

A települések infrastrukturális ellátottságát a lakásellátottsággal, a csatornahálózatba bekapcsolt lakások számával, a villamos energia fogyasztással és a hulladékgyüjtésbe bevont lakások számával jellemeztük. A térség összevont értékei ezekben a mutatókban meghaladják az országos átlagot, különösen érvényes ez a hulladékgyújtésbe és a csatornahálózatba bekapcsolt lakásokra. A megyék között jelentös különbségek vannak ugyanakkor, hiszen az aprófalvas Vas és Zala megye településeinek infrastrukturális ellátottsága kedvezőtlen, s magukon a megyéken belül is jelentős eltéréseket mutatnak.

A szociális infrastrukturális felszereltség mutatói; orvosok száma, kórházi ellátottság és az általános iskolák tanár ellátottsága alapján a térség helyzete átlag körüli, egyedül a kórházi ágyak száma emelkedik ki országos összevetésben. A 

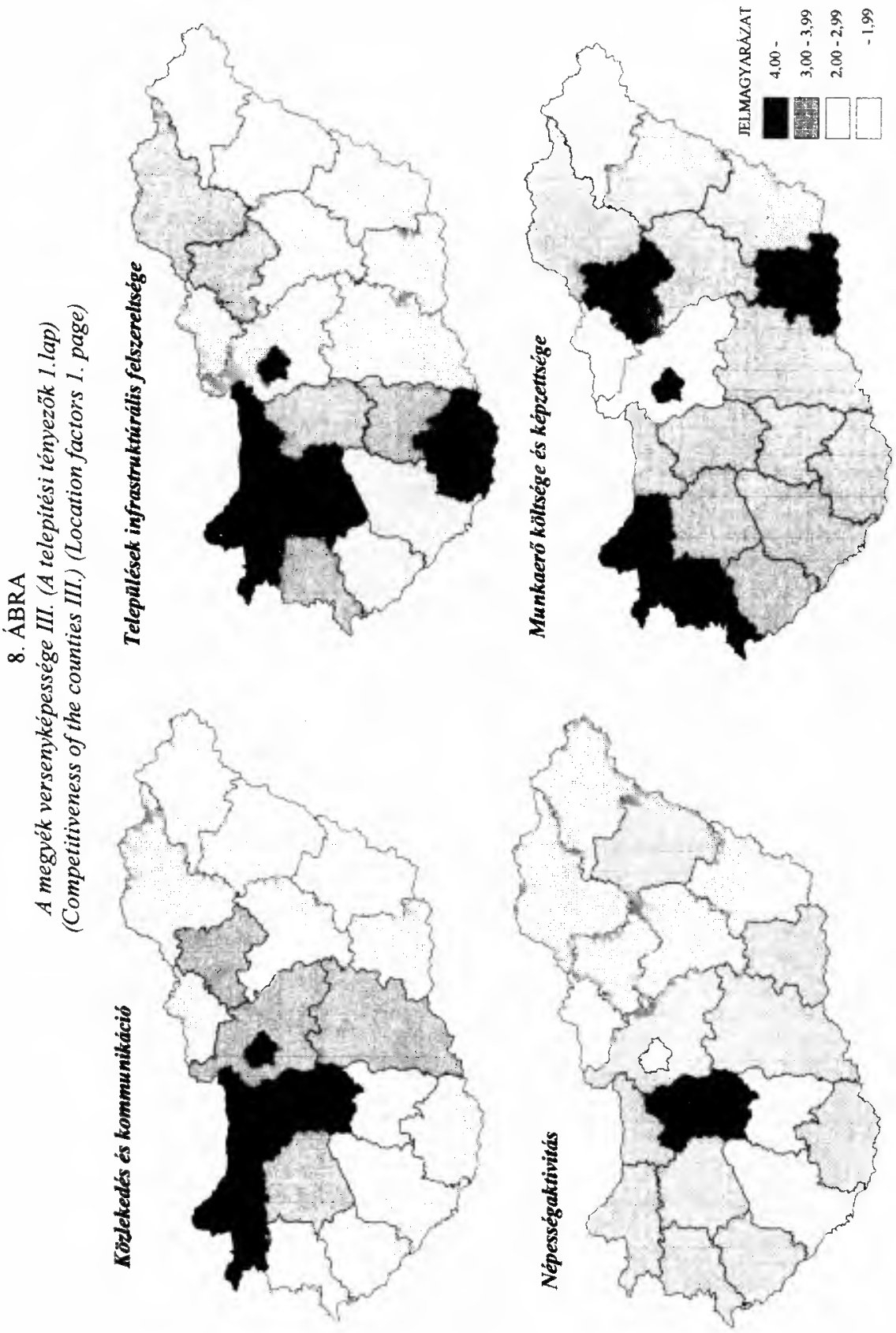


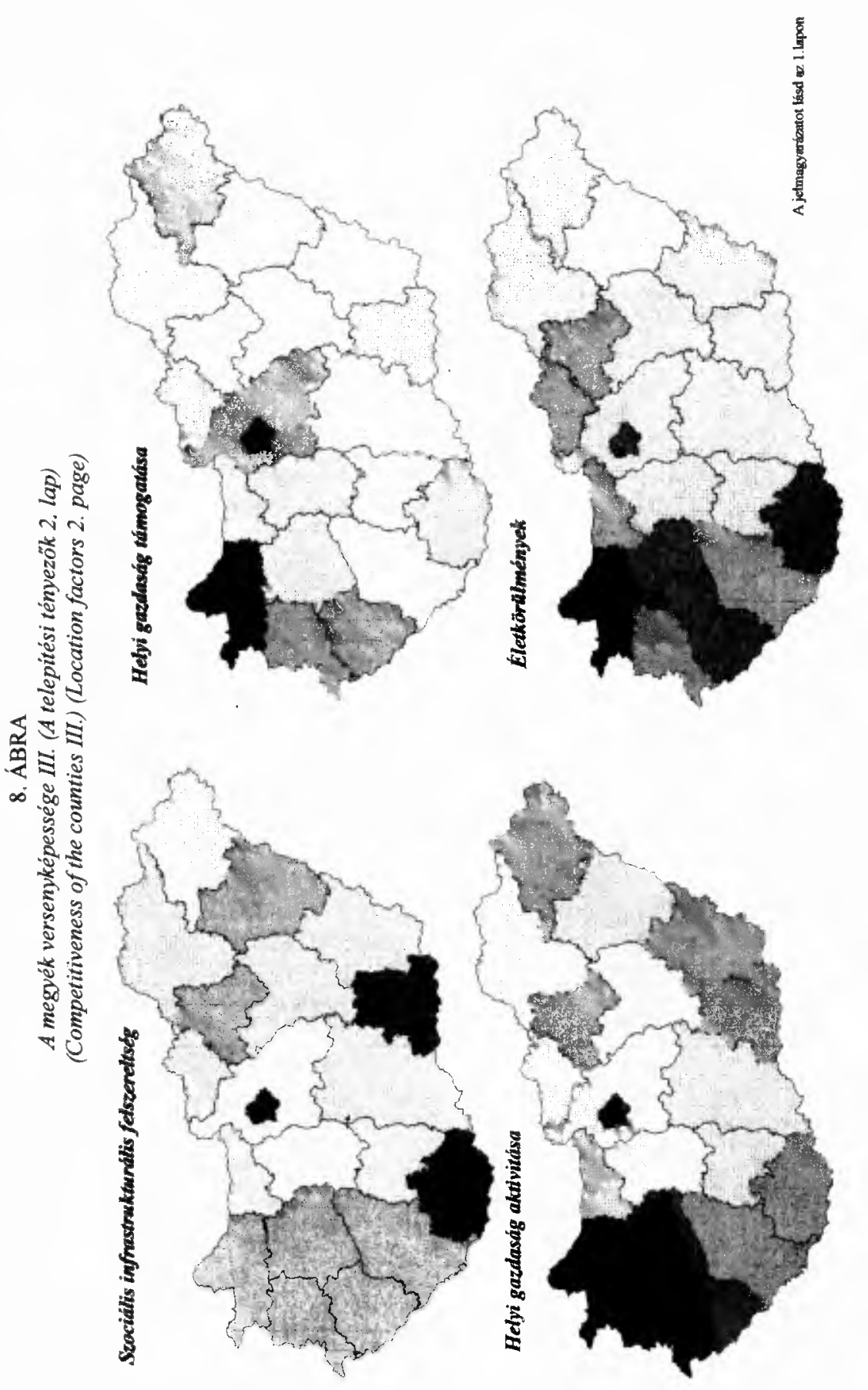


megyék között jelentös különbségek nincsenek, hiszen a meglévő intézményrendszer és felszereltség a kiegyenlítés elvei szerint jött létre. A lakossági szociális ellátórendszerek ugyan lehetőséget kínálnak szinvonalas üzemeltetésre, ám annak korlátait - az elkövetkező időszakban - éppen a létesítmények és a képzett apparátusok fenntartásának növekvő költségei fogják jelenteni, ami a területi különbségek újratermelöđéséhez vezet.

A helyi gazdaság támogatottsága, amelyet a vámszabadterületek száma, az iparüzési adót kivető települések aránya és a gazdaságfejlesztést szolgáló központállami alapokból elnyert támogatások összege jellemez, a térséget a jobban ellátott térségekhez sorolja. A térségben lassan kialakulnak azok a szolgáltatói infrastruktúrák, amelyek a piacgazdaságra jellemzőek, illetve növelik a telephely kínálatot (ipari parkok: Györ, Szentgotthárd, Ajka, inkubátorházak: Szombathely, Veszprém, Zalaegerszeg). A helyi gazdaság aktivitása következtében az önkormányzatok is támogatással élnek a letelepedéshez (telephely biztosítás, infrastruktúra kiépítésének támogatása, helyi adókedvezmény, lokális gazdaságfejlesztési programok), de jelentős szerepet vállalnak a központi gazdaságfejlesztést segítő támogatások megszerzésében is, amiből a térség kedvezỏ helyzete ellenére - részesedett.

A helyi gazdaság aktivitását a kereskedelmi forgalommal, a háztartások havi bruttó kiadásaival, a lakásárakkal (megyeszékhelyen), a személyi jövedelemadó nagyságával, az épített lakások számával és az önkormányzati kiadásokból a felhalmozás és tókejellegü kiadásokkal jellemeztük. Nos, ezen tényezöcsoport alapján a térség egésze az országos átlag feletti értékeket képviseli, talán egyedül a háztartások egy före jutó kiadásai esetében marad el valamivel attól. A térségben a lokális piac keresletét képviselö jövedelmek a profit szféra mellett a háztartásokban és a közszolgáltatásokat nyújtó önkormányzatokban magas, ami részben a fogyasztási szint tartós fennmaradását, annak minőségi bővülését vetíti elöre, részben pedig a közkiadásokon keresztül is gerjesztett lokális piacok fokozatos stabilitására utalnak. A megyék között természetesen vannak különbségek, hiszen ezen mutatók kimondottan kapcsolódnak a gazdaság teljesítményéhez, így GyőrMoson-Sopron és Veszprém megyében a helyi gazdaság aktivitása kimagasló, míg a másik két megyében valamivel mérsékeltebb, de jónak mondható.

Az utolsó tényezőcsoportnál megkíséreltük az életkörülmények néhány mutatóját értékelni, így a környezet minőségét a természetvédelmi területekkel, a kulturális kínálatot a színház- és kiállítás látogatók számával, a közbiztonságot a büncselekményekkel vagy a helyi társadalmat az alapitványok és egyesületek számával, illetve a felnőtt népesség adományozási aktivitásával jellemeztük. A térségben az életkörülmények az országos átlag felett vannak, a kulturális miliö sokoldalú, a helyi társadalom szervezỏdése élénk, a polgári hagyományok tovább élnek, ami vonzó körülményeket teremt a gazdasági lehetöségeknek, azok széleskörü hasznosításához. A térség egységesen kiváló minősítését Vas megye kedvezó értékelése azzal töri meg, hogy ott a színház hiányában a látogatottság az országos átlag alatt van, illetve a megyében a non-profit szervetek aránya sem haladja meg az országos szintet, viszont a közbiztonság mutatói a legkedvezőbbek, illetve a lakosság adományozási aktivitása is figyelemre méltó. 


\section{Térségfejlesztési üzenetek}

Az elemzésünk a gazdasági bázis modernizációt képviselö elemeire irányult, illetve a térség fontosabb jellemzőit megkíséreltük elhelyezni a gazdaság, s annak alakulását befolyásoló tényezók országos rendszerében. Megállapíthatjuk, hogy a térségi gazdaságban megkezdődött az átalakulás, azonban ennek üteme az egyes megyék szintjén eltérő mértékủ és intenzitású. Győr-Moson-Sopron megye gazdaságában a folyamatosan szerepet játszó nagyipar megerősödött, sőt annak hatására megindult a szolgáltatások és részben a kapcsolódó kis és középvállalkozások megtelepedése, így a gazdasági bázis, $s$ annak versenyképessége országos jelentőségü, a modernizáció üteme erỏteljes, miközben térbeli megjelenése is kiegyenlített. Vas megye vonatkozásában a gazdaság teljesítménye és az export ígéretesen növekedett, de ezt lényegében néhány nagyipari egység prođukálta, s azoknak területi (megyei) kapcsolatai még gyengék és esetiek, az elöremutató gazdasági szerkezetváltás egy-két településre koncentrálódik, a megye esetében egy sikeres modernizációs elmozdulást regisztrálhatunk. Zala ès Veszprém megye gazdasága a szerkezet-átalakítás induló fázisát éli, hiszen a külföldi tőke érdeklödése mérsékeltebb, viszont több gazdasági, település felszereltségi paraméter alapján új fejlődési pálya körvonalai lassan kirajzolódnak ki, viszont ezen két megye még számos - a gazdasági fejlődés szempontjából előremutató faktorban - elmarad a fejlődést hordozó magterülettől, illetve a gyorsabb fejlődést képviselö térségtöl.

A térség gazdasága, annak fejlöđési irányai és ađottságai nem egységesek, sőt jelentös kulönbségeket mutatnak, azt nem lehet éppen a gazdaságfejlesztés vonatkozásában valamiféle regionális szervezỏdésnek tekinteni. Fejlesztés irányait ennek alapján abban látjuk, hogy a helyi adottságok sokirányú fejlesztésével a megindult szerkezeti változások folytatódjanak, a lokális gazđasági miliő váljon egyre kedvezöbbé, miközben történjenek kísérletek a megyénken belüli és a térségen belüli gazdasági együttmüködések kialakítására, a termelési kooperációk élénkítésére. A területfejlesztés jelenlegi és jövőbeli eszközrendszere nem lesz képes a térség és a megyék gazdasági szerkezetének jelentős megújítására, annak alanyai maguk a gazdasági egységek voltak és lesznek a jövőben is. Viszont a térség szintü fejlesztés hozzájárulhat a gazđasági bázis müköđésének javitásához, egyrészt bizonyos (minimális) költségek internalizálásával (pl. telepítési tényezők, agglomerációs előnyök, letelepedési támogatások, képzés és oktatás), másrészt a versenyképesség növeléséhez (pl. térségi kooperációk, közlekeđési kapcsolatok javítása, $\mathrm{K}+\mathrm{F}$ bázisok támogatása). A kérdés az, hogy a korlátozott eszközrendszernek mi legyen a felhasználási iránya. Megítélésünk szerint a térségben, annak különösen a magterületein és centrumaiban a kis- és középvállalkozások müködési feltételeinek támogatására kell a hangsúlyt helyezni, továbbá a munkaerö képzettségének növelését célszerü szorgalmazni, annak tuđás szintjének folyamatos emelésével, s emellett a gazdasági egységek intraregionális kooperációjának megteremtéséhez, kiszélesítéséhez sokoldalú intézményrendszert érdemes müködtetni, miközben a telephelyi feltételek folyamatos javításáról sem lehet megfeledkezni. 


\section{Jegyzetek}

1 Az Észak-Dunántúlnak, mint potenciális régiónak ezen négy megyében történö kijelölése a kutatási megbizásban került meghatározásra, igy a vizsgálatokat ezen térségre végeztük el. A tanulmányban következetesen kerüljük a régió fogalom használatát, a négy megye által alkotott feltételezett területi egységre a térség fogalmat használjuk.

2 A térségben realizálódott 1993. végére a vidékre települt kulfóldi érdekeltségü vállalkozások jegyzett tökéjének 22,8\%-a, míg 1994-ben a jegyzett tökének a 23,7\%-át fogadta a régió, így vidéki viszonylatban a vezetỏ helyét változatlanul megtartotta.

3 Vas-Györ-Moson-Sopron-Veszprém-Komárom-Esztergom megye határán.

${ }^{4}$ Városhiányos övezet Györ-Moson-Sopron-Vas-Veszprém megye megyehatár menti térségei.

5 Vas és Veszprém megye aprófalvas térségei.

${ }^{6}$ A nyugat-keleti összeköttetést lényegében csak a 8-as föutvonal és a 85-ös út biztosítja, amelyeknek a nemzetközi forgalma is számottevő, így a térségen belul csak nagy rảfordításokkal valósithatók meg a belső kapcsolatok. Ugyanakkor ezeknek a keresztirányú utaknak az áteresztö képessége már jóval meghaladja azok lehetséges felsô terhelési szintjét, azaz már napjainkban is akadályozzák a kialakuló együttmúködéseket. Rövid távon a 8-as, a 81 -es, 85 -ös és 86-os utak átfogó felújítása a térség fejlődése szempontjából nélkülözhetetlen.

${ }^{7}$ A térség iparával foglalkozó fejezetben részletesen kitérünk a szerkezetalakításban meghatározó szerepet játszó kullföldi befektetésekkel.

${ }^{8}$ A vállalkozásokra alapvetően jellemzö, hogy a valójában végzett vagy tervezett tevékenységek mellett még számtalan elképzelt tevékenységet is megjelölnek az alapításkor. Ezek nagy részét nem vagy csak kimondottan ritkán végzik, azaz tevékenységūk súlypontiába nem tartoznak. A Cégbíróság által bejegyzett szervezetek kigyújtésekor arra tơrekedtünk, hogy feltüntessük a vallasztott tevékenységekben az általunk fontosnak nevezett szolgáltatásokat, igy lényegében nem a vállalkozások száma, azok sürüsége jelenik meg az ábrákon, hanem a tevékenységi sürüség, azaz az 1000 lakosra jutó kiemelt szolgáltatások kínálata, ami lényegében csak egy potenciális kínálat, valójában csak mérsékelten müködik, azoknak az igénybevétele kimondottan korlátozott.

9 Az adatok egységesen 1994-re vonatkoznak, illetve az 1994. évi adatokra vetítve végeztük el az osszehasonlitásokat. Az egyes változóknál az országos szintủ értékeket (amelyben természetesen Budapest is szerepelt) vettük átlagnak, majd az attól való elterést számítottuk és ennek alapján állítottunk fel öt kategóriát. Az igy képzett ötfokozatú skála jelentette a megyék értékelését egy-egy tényezỏnél, majd ezek átlaga adta a blokkra vonatkozó együttes értéket.

${ }^{10}$ A Központi Müszaki Fejlesztési Alap a legjelentösebb kormányzati támogatási forrása a $\mathrm{K}+\mathrm{F}$ tevékenységnek Magyarországon.

"Tudományos minősítéssel rendelkezỏ személyeknek azokat tekintettuk, akik Ph. D. (korábban a tudomány kandidátusa) és a D. Sc. (korábban tudomány doktora), valamint akadémiai tagsággal rendelkeztek és az adott megyében éltek.

${ }^{12} \mathrm{Az}$ egyes elemekre vonatkozó adatoknál a legfrissebb értékeket használtuk fel, így azok 1994-re vonatkoznak.

\section{Irodalom}

Az Északnyugat-Dunántúl területfejlesztési stratégiája. I. kôtet A régió Európában és a magyar térszerkezetben. II. kötet A fejlesztés endogén forrásai. Témavezető: Rechnitzer J. MTA RKK NYUTl. Györ. 1995. Kézirat.

Nemes Nagy J. (1995) Az Északnyugat-Dunántúl a piaci átmentben. MTA RKK NYUTI, Györ. Kézirat. Hrubí L. (1995) Északnyugat-Dunántúl gazdaságának általános értékelése. MTA RKK NYUTI, Györ. Kézirat. 


\title{
ECONOMIC ENDOWMENTS AND COMPETITIVE ADVANTAGES OF THE NORTHWEST TRANSDANUBIAN REGION
}

\author{
JÁNOS RECHNITZER
}

The essay analyses the economic conditions of a region comprising four counties, Györ-Moson-Sopron, Vas, Veszprém and Zala, trying to explore the common features of them and the possible regional particularities in the economic structure.

The region as a whole is in a favourable position in the Hungarian modernisation, although it is not homogeneous but divided. The author demonstrates, with the appearance of the businesses, the significant regional differences behind the above national average development dynamics of the region. In Gyor-Moson-Sopron county mainly capital intensive businesses settled down, while in the other counties those organisations which need less investments, rather business will and initiatives. The structure of the region is not homogeneous with respect to the economic capacity, either. The region along the Hungarian border with Austria is the main attraction for foreign inward investment, escorted by a zone from the State border to Gyór and the more and more spectacular development zone between Györ and Sopron. The third growth axis is along Lake Balaton where tourism is the dominant sector. The fourth new development zone is the axis between the towns of Veszprém and Ajka, which is more and more organically connected to the other centre of the Hungarian modernisation, Székesfehérvár (which is already out of the region).

In the renewal of the economic structure, the role of the foreign capital is decisive, as $46.9 \%$ of the organisations and $40.9 \%$ of the capital assets in the Hungarian countryside are in this region, which means that $23.8 \%$ of foreign inward investments in Hungary was realised in Nortwest Transdanubia (1994). The biggest investor was Germany, followed by Austria with smaller scale but several investments. Foreign interest can be found all through the economy, its role has become dominant in all sectors by now. The foreign economic connection of the region is also determined by foreign investments: The growing volume of exports to and imports from Germany characterise the direction of the economic links, at the same time the number of cooperations with Austria has been declining. A new orientation of the economy of the region is towards Italy, especially in import relations.

In the employment structure of the region the proportion of industry is still dominant, but in some counties we can see a moderate increase in the share of the service sector. The proportion of the employees in modern business services is not high (3-3.2\%), indicating that although these activities are present in the economies of the counties, they are not significant. Among the economic organisations of the region the proportion of those whose activity is in economic and business services is high $(17.9 \%)$, it does not mean, however, that their performance is significant. The 
unemployment rate is below the national average in the region, in fact, it is still decreasing (in Zala and Veszprém) or stagnating at a low level (Györ-MosonSopron and Vas). This indicates that only the first two counties have considerable employment reserves.

The essay examines the region and its counties in a national comparison. The competitiveness of the region is evaluated by the economic performance, the development possibilities and the location factors. By the indices worked out for the analysis, this region is in a relatively favourable position by Hungarian standards, in fact, we can say that its competitiveness is excellent. The performance of the economy, characterised by the volume of GDP, the dynamics of investments, unemployment and the volume of industrial export, is the best in Hungary in GyorrMoson-Sopron and Vas counties, and is also good in the other two counties. The development possibilities were evaluated by several groups of factors, i.e. the tertiary economy, business and capital activity and innovation potential. The economic performance and business and capital activity of Nortwest Transdanubia lags behind its innovation potential, i.e. the resources for internal renewal are limited, the external economic-development dependence of the region is high, so to say dominant. The location factors were analysed by 34 factors in 8 groups. We can draw the conclusion that the whole of the region is in a favourable situation by Hungarian standards, at the same time it is divided and does not show a homogeneous picture.

Finally the essay states that the pace of economic modernisation is faster in this region than in other parts of Hungary, but the signs of regional organisation are not yet visible. The direction of the future developments is in local economic development, but the strengthening of the regional connections of the economic base in different directions is also necessary. 